\title{
Sedimentology and fossil vertebrates of the Santa Cruz Formation (early Miocene) in Lago Posadas, southwestern Patagonia, Argentina
}

\author{
*José I. Cuitiño ${ }^{1}$, Sergio F. Vizcaíno ${ }^{2,3}$, M. Susana Bargo ${ }^{2,4}$, Inés Aramendía ${ }^{5}$
}

\author{
I Instituto Patagónico de Geología y Paleontología (IPGP, CCT CONICET-CENPAT). Boulevard Brown 2915, Puerto Madryn \\ (9120), Chubut, Argentina. \\ jcuitino@cenpat-conicet.gob.ar \\ 2 División Paleontología de Vertebrados, Museo de La Plata, Unidades de Investigación Anexo Museo, 60 y 122, La Plata (1900), \\ Argentina. \\ vizcaino@fcnym.unlp.edu.ar; msbargo@fcnym.unlp.edu.ar \\ 3 Consejo Nacional de Investigaciones Cientificas y Técnicas (CONICET) Argentina. \\ ${ }^{4}$ Comisión de Investigaciones Científicas (CIC), calle 526 entre 10 y 11, 1900 La Plata-Buenos Aires, Argentina. \\ 5 Instituto Patagónico para el Estudio de Ecosistemas Continentales (IPEEC, CCT CONICET-CENPAT). Boulevard Brown 2915, \\ Puerto Madryn (9120), Chubut, Argentina. \\ aramendia@cenpat-conicet.gob.ar
}

*Corresponding author: jcuitino@cenpat-conicet.gob.ar

\begin{abstract}
Lago Posadas is located at the foot of the Southern Patagonian Andes, in southwestern Argentina, where the early Miocene Santa Cruz Formation (SCF) shows thick and laterally continuous exposures. This region has been scarcely explored for fossil vertebrates since the first efforts by J.B. Hatcher in 1898-99. In this contribution, we performed sedimentologic and paleontological studies in order to reconstruct depositional environments and the associated fossil vertebrate fauna. Sedimentologic data suggest that the sedimentary record begins with restricted marine-estuarine deposits grading upward to fluvial floodplains and fluvial channels. Extensive floodplains, occasionally interrupted by low-sinuosity, sand-dominated channels, show dominant reddish coloration, moderate to low paleosol development, abundant crevasse splay sandstones and lack of vegetal remains, suggesting deposition in a low gradient, oxygenated setting under elevated sedimentation rates. Vertical stratigraphic trends are subtle, suggesting little paleoenvironmental changes during deposition of the whole SCF in this region. Paleocurrent directions, sandstone composition and paleogeographic reconstructions all indicate that deposition of the SCF was strongly associated to the contemporaneous uplift of the Andes. Fossil vertebrates analyzed are the result of our collecting effort and revision of museum collections. The faunal assemblage includes 31 taxa: 28 mammals and three birds. Mammals belong to the main groups recorded in other areas of the SCF (metatherians, xenarthrans, notoungulates, litopterns, astrapotheres and rodents). The assemblage allows a Santacrucian Age sensu lato assignment for the fauna at Lago Posadas. Taxonomic revisions of several taxa are necessary to further adjust the biostratigraphic significance of this association. The combined record of arboreal, browser and frugivores, on one side, and grazer mammals and rheas, on the other, suggest the presence of both trees and open environments. Frugivores, among primary consumers, and the secondary consumers guild are under-represented due to sample and fossil remain size biases. The sedimentologic and paleontological record of the SCF in Lago Posadas suggests that the uplift of the Southern Patagonian Andes acted as a primary control on basin subsidence and sediment supply, providing a special signature for sub-andean localities. However, previously registered climatic changes are poorly recorded in this study.
\end{abstract}


RESUMEN. Sedimentología y vertebrados fósiles de la Formación Santa Cruz (Mioceno temprano) en Lago Posadas, suroeste de Patagonia, Argentina. Lago Posadas se ubica al pie de los Andes Patagónicos Australes, en el suroeste de Argentina, donde la Formación Santa Cruz (FSC) del Mioceno temprano muestra afloramientos potentes y lateralmente continuos. Esta región ha sido escasamente explorada en relación con sus vertebrados fósiles desde los primeros esfuerzos de J.B. Hatcher en 1898-99. En esta contribución, se presentan estudios sedimentológicos y paleontológicos con el fin de reconstruir los ambientes deposicionales y la fauna de vertebrados asociada. Los datos sedimentológicos sugieren que el registro sedimentario comienza con depósitos marinos-estuarinos restringidos, que gradan a depósitos de planicies de inundación y canales fluviales. Dichas planicies, ocasionalmente interrumpidas por canales arenosos, muestran colores rojizos dominantes, pobre a moderado desarrollo de paleosuelos, abundantes depósitos de desbordes y ausencia de restos vegetales, lo cual sugiere depositación en ambientes oxigenados de bajo gradiente, con altas tasas de sedimentación. Las tendencias estratigráficas verticales son tenues, lo que indicaría cambios ambientales menores durante la depositación. Las direcciones de paleocorrientes, la composición de areniscas y la reconstrucción paleogeográfica indican que la acumulación de la FSC estuvo asociada al levantamiento Andino contemporáneo. Los vertebrados fósiles analizados son el resultado del esfuerzo propio de colecta y de colecciones de museos. La asociación faunística incluye 31 taxa: 28 mamíferos y tres aves. Los mamíferos pertenecen a los grupos principales registrados en otras áreas en la FSC (metaterios, xenartros, notoungulados, litopternos, astrapoterios y roedores) y permiten asignar una edad Santacrucense sensu lato a la fauna de la FSC de Lago Posadas. Son necesarias revisiones taxonómicas de varios taxa para mejorar el significado bioestratigráfico de esta asociación. La combinación del registro de arborícolas, ramoneadores y frugívoros por un lado, y mamíferos pastadores y ñandúes por el otro, plantearía la presencia tanto de árboles como de ambientes abiertos. Los frugívoros, entre los consumidores primarios, y el nicho de los consumidores secundarios, se encuentran subrepresentados debido a sesgos en el tamaño de los fósiles como en el tamaño del muestreo. El registro sedimentológico y paleontológico de la FSC en Lago Posadas sugiere que el ascenso de los Andes Patagónicos Australes ha actuado como un control primario sobre la subsidencia y el aporte de sedimentos, y ha otorgado características distintivas a las localidades subandinas. Sin embargo, los cambios climáticos previamente postulados, están pobremente registrados en este estudio.

Palabras clave: Análisis de facies, Paleoecología, Cuenca Austral, Santacrucense, Burdigaliense, Sistemas fluviales.

\section{Introduction}

The Santa Cruz Formation (SCF) is one of the most relevant stratigraphic units of southern South America in terms of Miocene terrestrial stratigraphic record and vertebrate paleontology. It is widely distributed in southern Patagonia, being part of the synorogenic deposits of the Austral (or Magallanes) Basin and representing a sedimentary archive of a period that unraveled significant environmental changes in the region, driven mostly by the uplift of the adjacent Andean orogenic belt (Blisniuk et al., 2005; Ghiglione et al., 2016a). Vertebrate fossils from this unit have been collected since 1845 especially in the southern and eastern parts of Santa Cruz Province, and thousands of specimens, mostly mammals, are preserved in museums around the world (Vizcaíno and Bargo, 2013; Vizcaíno et al., 2013, 2016a). They constituted the basis for the establishment of the early Miocene Santacrucian South American Land Mammal Age (SALMA; Pascual et al., 1965).

Santacrucian sensu lato fauna is also present in the West, in the Andes or nearby, from Río Turbio and Lago Argentino in the South, to Río Pinturas (Pinturas Formation) and Lago Posadas in the North.
The lower levels at some of these localities show faunal peculiarities that have been traditionally considered as corresponding to earlier stages than the typical Santacrucian faunas from exposures along the Río Santa Cruz and the Atlantic coast (Ameghino, 1906; Simpson, 1940; Marshall et al., 1983; Kramarz and Bellosi, 2005). Recently, Cuitiño et al. (2016) proposed that the temporal scenario now available (see below) suggests that at least some of these faunal differences must reflect ecological or geographic, rather than temporal, factors.

From a geologic perspective, the terrestrial deposits of the SCF are a significant element for the reconstruction of the Miocene paleoenvironments and the tectonic history of the adjacent Southern Patagonian Andes, which had been uplifted simultaneously to the deposition of this unit (Fosdick et al., 2013; Ghiglione et al., 2016a, b). The Miocene Andean uplift represents a major control on the paleogeographic reconfiguration as well as on the climatic systems of southern Patagonia (Blisniuk et al., 2005; Palazessi et al., 2014) that supposes significant environmental changes that should be recorded to some extent in the adjacent foreland basin deposits and its associated fossil content. 
In this sense, Lago Posadas, located in the northwest of the Santa Cruz Province, is a key locality for studying the depositional environments and paleontology of the SCF for several reasons: a. the exposures are abundant, thick, laterally continuous and of variable quality; $\mathbf{b}$. it is one of the few relatively accessible areas today in the remote northwestern sector of the Austral Basin; c. it is located at the foot of the Andes, where few studies for the SCF are available in the literature; $\mathbf{d}$. it has been the focus of historical paleontological expeditions for fossil vertebrates; e. its age is relatively well established (Blisniuk et al., 2005; Cuitiño et al., 2015).

Although some paleoenvironmental interpretations have been made for the SCF in Lago Posadas (e.g., Giacosa and Franchi, 2001; Blisniuk et al., 2005), we know little about the stratigraphy, sedimentology, composition, paleoenvironments of deposition and paleoecology of the associated fauna for this unit in the northwestern sector of the Santa Cruz Province. The SCF in Lago Posadas yielded fossil vertebrates that were first collected by the pioneer expeditions by John B. Hatcher (Princeton University; PU) in 1898 and 1899, and described in the Reports of the Princeton University Expeditions to Patagonia, 1896-1899 (Hatcher, 1903). After more than a century from those discoveries, neither thorough paleontological work have been carried out nor publications about the area are available.

The objective of this work is to provide new field sedimentologic descriptions and to update the fossil vertebrate composition, based on recent fieldwork and a revision of museum collections, from this historic locality of northwestern Santa Cruz Province. We aim to integrate geologic and paleontological information in order to reappraise this locality and to integrate it in a broader geologic, paleontological and paleoenvironmental framework. We provide novel data for the reconstruction of the Miocene paleoenvironments and vertebrate paleoecology of southern Patagonia as well as some hypotheses about the evolution of the foreland basin associated to the uplift of the Southern Patagonian Andes.

\section{Geologic and paleontological background}

\subsection{Geology of the study area}

The study area is located in the northwest of the Santa Cruz Province (Patagonia, Argentina), at the foot of the Southern Patagonian Andes and the northern end of the Austral Basin. Lago Posadas is a small lake next to the larger Lago Pueyrredón, both located in a glacial trough oriented NW-SE. Hatcher $(1900,1903)$ refers to the area of Lago Posadas, i.e., between the Río Furioso to the west, and Río Tarde to the east (Fig. 1), as "Lake Pueyrredon". Fossil vertebrates coming from the SCF in this area collected by the Princeton University expeditions are also catalogued as coming from "Lake Pueyrredon".
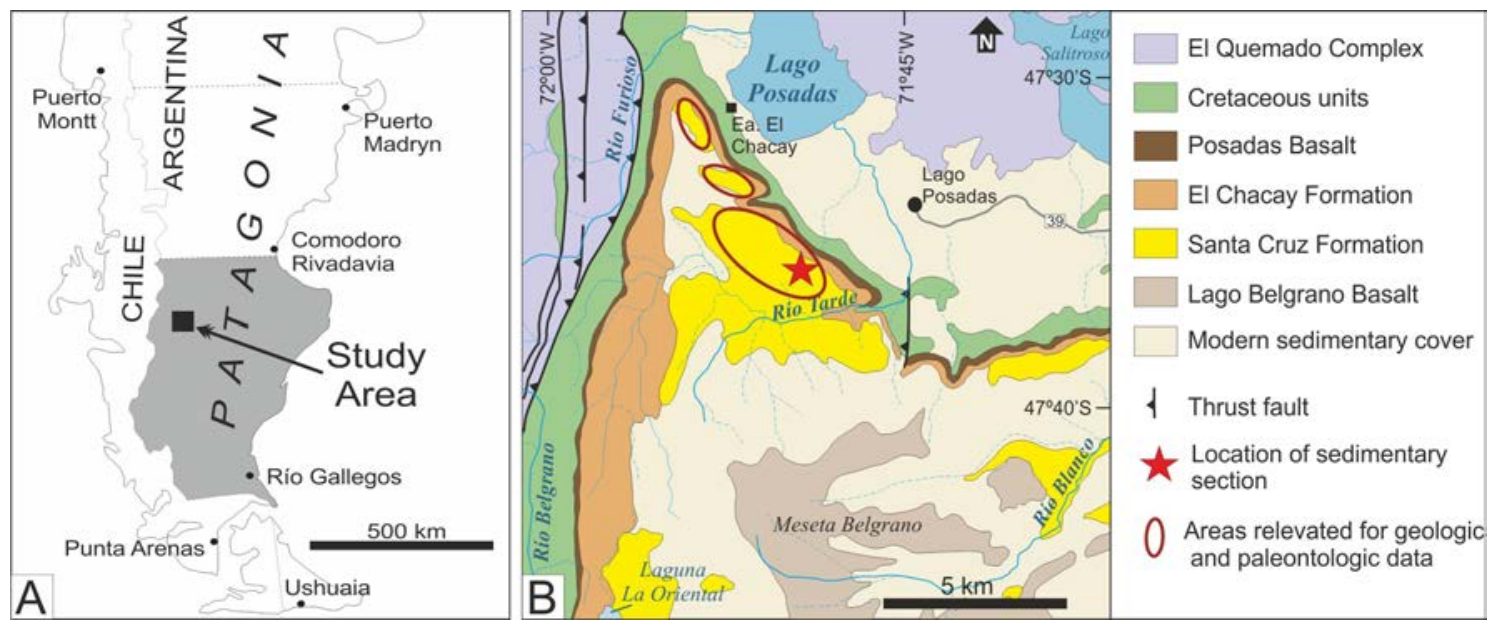

FIG. 1. Location map of the study area. A. Regional geographic map showing the location of the area mapped in B. The gray area corresponds to the Santa Cruz Province; B. Simplified geologic map of Lago Posadas and surrounding areas. The prospected areas and the position of the sedimentary section are indicated. Modified after Giacosa and Franchi (2001) and Cuitiño et al. (2015). 
The study area shows exposures of the CretaceousMiocene infill of the Austral (or Magallanes) Basin (Giacosa and Franchi, 2001). The section of the SCF studied herein is exposed along the north margin of the Meseta Belgrano (Fig. 1), where several older stratigraphic units are also exposed. North of this margin, a wide and deep glacial valley develops, exposing the basement volcaniclastic rocks of the basin assigned to El Quemado Complex (Mid to Late Jurassic). To the west, cretaceous sedimentary units are exposed, including the marine Springhill, Río Mayer and transitional Río Belgrano formations, all mapped as "Cretaceous units" in figure 1 . Above the former and outcropping at the base of the Lago Posadas-Meseta Belgrano cliffs, is the Río Tarde Formation (Aptian; Ghiglione et al., 2015) which is covered by the Eocene Posadas Basalt, which in turn is covered by the early to middle Miocene marine and continental deposits. The early Miocene marine deposits are considered as part of the Patagonian Transgression and were formally named as the El Chacay Formation (Chiesa and Camacho, 1995; Cuitiño et al., 2015), which in turn are followed by the continental deposits of the SCF. The top of the Miocene succession in this area, roughly about 1200$1,400 \mathrm{~m}$ above sea level ( $\mathrm{m}$ a.s.1.), is truncated by an erosional surface which forms a plateau slightly dipping to the east. South of the northern margin and forming the core of the Meseta Belgrano is the Belgrano Basalt (late Miocene; Gorring et al., 1997) (Fig. 1), which is located at the highest elevation within the plateau reaching up to $2000 \mathrm{~m}$ a.s.l.

\subsection{Previous geo-paleontological studies of the SCF in the area}

The first mention regarding the Miocene continental deposits and its fossil content in this area is that of John Bell Hatcher (Hatcher, 1900, 1903), who visited the area for the first time in 1898 as part of the Princeton University Expeditions to Patagonia. Hatcher climbed the cliffs of the eastern end of what he first called "Lake Princeton", but time after recognized that the name Pueyrredón had priority (Hatcher, 1903). Detailed descriptions of the geography and geology of the area by Hatcher allow confirming that the exposures he visited are the same as that we describe in this work (Fig. 2). There Hatcher made a collection of vertebrate fossils from the beds he called the "Santa Cruzian formation" (Hatcher, 1903). The discovery of several vertebrate taxa, including a phorrusrhacoid bird, the notoungulate Nesodon, litopterns and carnivorous marsupials, allowed him to consider this fossil association as having a Santacrucian Age. Hatcher went back to the area in 1899 with Barnum Brown from the American Museum of Natural History (AMNH, New York, USA). They stayed a longer period, making a larger collection of Santacrucian fossil vertebrates. Most of his collection is nowadays in the Yale Peabody Museum (YPM, New Haven, USA), and a few, mostly unprepared, specimens are in the AMNH. Since then, few paleontological expeditions visited the area, probably due to the difficulty for accessing these outcrops. There was a lack of effort in making a systematic collection of new fossils, excepting brief visits by a team from the Museo de La Plata (MLP, Argentina) in 1984, and a joint expedition of the Universidad Nacional de la Patagonia San Juan Bosco (UNPSJB, Argentina) and the State University of New York at Stony Brook (SUNY, USA) in 2007 (González Ruiz, 2012).

In regard to the stratigraphic and sedimentologic knowledge, the SCF in this area is relatively unknown in comparison to other better known localities of Santa Cruz Province. Most studies were focused on easily accessible, fossiliferous equivalent strata in the southeast (Tauber, 1994, 1997a, b; Matheos and Raigemborn, 2012; Vizcaíno et al., 2012a; Raigemborn et al., 2015), or central-western (Fernicola et al., 2014; Cuitiño et al., 2016) areas of the province, or nearby Pinturas Formation in the west (Bown and Larriestra, 1990; Fleagle et al., 1995; Kramarz and Bellosi, 2005). Probably, the abundance of fossil vertebrates in those localities prompted the continuous interest of geoscientists. Albeit widely distributed, descriptions of the SCF in the southwest of Santa Cruz Province are scarce (Furque, 1973; Giacosa and Franchi, 2001; Cuitiño and Scasso, 2010; Bostelmann et al., 2013; Cuitiño et al., 2014, 2016). Besides Hatcher, the oldest geological description of the SCF deposits of the study area corresponds to Riggi (1957), who described the regional stratigraphy of the area south of lakes Posadas and Pueyrredón. In this contribution the author described $100 \mathrm{~m}$ of the marine Patagonian beds (currently the El Chacay Formation, Chiesa and Camacho, 1995) overlying directly on the Posadas Basalt. Conformably covering the marine deposits, the author describes the Santacrucian (currently the SCF), a succession of continental mudstones, sandstones and few conglomerates that reach 800 m-thick. 

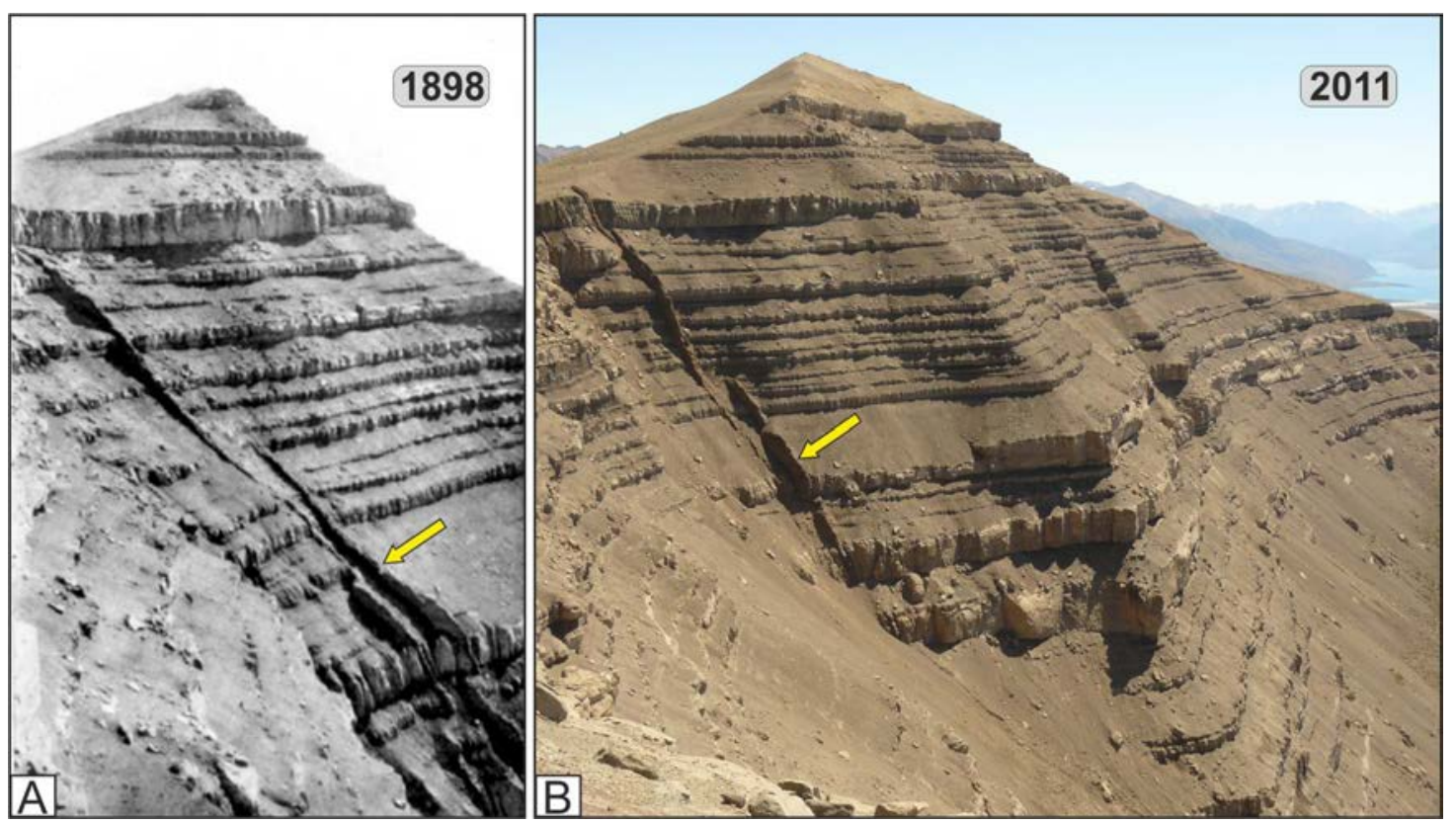

FIG. 2. Two photographs of the same exposure of the SCF in one of the cliffs south of Lago Posadas, obtained with 113 years of difference. Yellow arrows point to a vertical basaltic dike that clearly indicates both pictures correspond to the same place. A. Photograph taken by John B. Hatcher during his expedition in 1898 (Hatcher, 1903: fig. 14); B. Photograph taken by us (JIC) during field work in 2011. In the background the Lago Pueyrredón and the Andean cordillera are visible.

Other mentions to these continental strata are included in regional studies, which provide little new data. Feruglio (1949) mentioned 500 m of continental Santacrucian deposits for the Lago Posadas region without detailed descriptions. Zambrano and Urien (1970) and Russo and Flores (1972), referring to all Miocene continental deposits overlying the Patagonian marine deposits of Austral Patagonia, used the term SCF for the first time. Ramos (1989) described more than $800 \mathrm{~m}$ of intercalated sandstones and mudstones rich in vertebrate fossils in the southwestern margin of Meseta Belgrano, which he assigned to the SCF.

More recently, Giacosa and Franchi (2001) added some descriptions of the sediments composing the SCF and mapped its distribution around the Meseta Belgrano and adjacent areas. Blisniuk et al. (2005) provided radiometric ages for the SCF within the study area and several stable isotope analyses from paleosol carbonate nodules, which allow the authors to estimate some climatic changes, occurred during the deposition of the unit and related to the Andean uplift. Bande (2007) described the lower part of the SCF and interpreted a fluvial paleoenvironment of deposition. Cuitiño et al. (2015) described and dated the underlying marine deposits, including the transitional deposits and the lower $20 \mathrm{~m}$ of the SCF in the area, and suggested the later was deposited in a low energy fluvial setting. In agreement with the original proposal of Feruglio (1938), the authors highlighted the conformable and gradational passage between the underlying shallow marine deposits and the low-energy fluvial deposits of the SCF above.

Ugarte (1956) defined the Río Zeballos Group to include all the continental Miocene deposits that crop out in the western and southern border of the Meseta del Lago Buenos Aires, just north of the study area. This group includes from base to top the Río Jeinimeni, the Cerro Boleadoras and the Río Correntoso formations, and compose a coarsening upward succession, from mud dominated strata at the base, to gravel dominated strata at the top (Ugarte, 1956; Dal Molin and Colombo, 2003). Other contributions correspond to De Barrio et al. (1984) who described the lithology and vertebrate paleontology of the SCF deposits to the east of the study area. Part of the beds described by De Barrio et al. (1984) where later defined as Pinturas Formation by Bown and Larriestra (1990) in the surroundings of the Río Pinturas, some $100 \mathrm{~km}$ northeast of the study area. 
The age of the SCF in Lago Posadas is based on six ${ }^{40} \mathrm{Ar} /{ }^{39} \mathrm{Ar}$ dates provided by Blisniuk et al. (2005), with an age span of 22-14 Ma. Based on regional tephrochronology and sedimentation rates estimations, Perkins et al. (2012) questioned the age for the lower strata of the SCF of Lago Posadas and concluded it should be close to $18 \mathrm{Ma}$. The latter was also supported by Cuitiño et al. (2015) based on Sr-stratigraphy for the underlying marine deposits, whose younger beds are chronologically located in $18 \mathrm{Ma}$. These age estimations provide an age span of roughly $4 \mathrm{my}$, from $18 \mathrm{Ma}$ to $14 \mathrm{Ma}$, for the SFC in Lago Posadas. A note of caution has to be made related to the younger age $(14.24 \pm 0.78 \mathrm{Ma})$ obtained by Blisniuk et al. (2005), since the stratigraphic position of this dated level corresponds to a tuff located $3 \mathrm{~m}$ beneath the top of the SCF in a place located $10 \mathrm{~km}$ southeast of the locality studied herein. That locality, shows thicker exposures of the SCF, which means that the dated level is probably not represented in the locality studied in this work and consequently the age of the top of our section should be somewhat older than $14.24 \pm 0.78 \mathrm{Ma}$.

\section{Materials and Methods}

Geological and paleontological fieldwork was conducted in the area in three opportunities since 2010. Geological observations in the field included measurement and facies description for a sedimentary column located in the northern border of Meseta Belgrano, just south of Lago Posadas ( $47^{\circ} 35^{\prime} \mathrm{S} ; 71^{\circ} 51^{\prime} \mathrm{W}$ ), in one of the most complete sections for the unit (Fig. 1). This section is close to that measured by Blisniuk et al. (2005). Observations include bed thickness and geometry, sedimentary structures, grain size, paleocurrent directions as well as sampling for sandstone composition.

Besides the stratigraphic section, for some extended lateral exposures, the $2 \mathrm{D}$ geometry of sandstone bodies was evaluated by means of the width to thickness (W/T) ratio (Gibling, 2006), taking care of observing outcrop faces oriented perpendicular to mean paleocurrent directions. Paleocurrent directions were measured in cross bedded sandstones when a $3 \mathrm{D}$ exposure of the bed allows determining the true dipping direction. These were complemented in nearby outcrops between Río Furioso and Río Tarde (Fig. 1) that allowed 3D examination of sedimentary bodies. Lithofacies analysis was done following the criteria of Miall $(1985,1996)$, from which most of the lithofacies codes were taken.

Coarse to medium sandstones were sampled for petrographic studies, selected from thick and indurated beds at stratigraphic intervals of approximately $40 \mathrm{~m}$, covering the complete thickness of the studied strata. These were analyzed in thin section under polarized microscope and, in order to obtain a quantitative compositional scheme, 450 grains were counted for each. Sandstones are classified following the Q.F.L. (quartz, feldspar and rock fragments) ratios following Folk et al. (1970) and the tectonic provenance diagrams of Dickinson et al. (1983).

In total, paleontological prospecting and collecting efforts sum eight days of an experimented field paleontologist. The specimens collected belong to the Museo Regional Provincial P.M.J. Molina (MPM; Río Gallegos, Santa Cruz Province, Argentina). In addition, the collections made by Hatcher for PU (currently at YPM), Brown for the $\mathrm{AMNH}$, and Rosendo Pascual and others for the MLP, were studied. The material revised is listed in Appendix 1.

A preliminary paleoecological analysis of the fauna recorded in Lago Posadas was performed following a general protocol based on body mass, diet and substrate preference and use (Vizcaíno et al., 2016b), applied by Kay et al. (2012) and Toledo (2016).

Body mass values and dietary and substrate preference and use categories were estimated by direct assignation to genera present in the Atlantic coastal exposures of SCF analyzed by Kay et al. (2012: Table 17.1). Mass values and categories for the genera not present in the coastal fauna were taken from Toledo et al. (2014) and Toledo (2016) for the sloths, Cassini et al. (2012) and Muñoz (2017) for notoungulates. M.E. Pérez (personal communication, 2017) provided mass estimation for the rodent Schistomis rollinsi, not present in the coastal fauna.

\section{Results}

\subsection{Sedimentology and facies analysis}

In order to provide order to the field sedimentologic data for the SCF in Lago Posadas, twelve lithofacies were discriminated (Table 1), which are grouped into three Facies Associations (FA), namely FA 1, FA 2 and FA 3. 
TABLE 1. DESCRIPTION AND INTERPRETATION OF LITHOFACIES FOR THE SCF IN LAGO POSADAS.

\begin{tabular}{lll}
\hline Name Description & Interpretation \\
\hline
\end{tabular}

B Densely packed, lenticular bioclastic deposits formed by the oyster Crassostrea orbignyi. Articulated and disarticulated specimens are present. Beds rarely are thicker than $1 \mathrm{~m}$ and are laterally discontinuous.

Ht Heterolithic deposits composed of a millimeter to-centimeter-thick alternation of fine sandstones and mudstones. Current ripple lamination is common in sandstone layers.

Fl Laminated claystones and siltstones. Desiccation cracks are present in some occasions.

Fm Structureless, dark reddish mudstones. Occasionally grey colored.

Fr

Dark reddish, greenish to gray mudstones with pedogenic structures such as mottles, rhizoliths, cutans and soil aggregates.

Sm Moderately to well sorted, massive fine to medium sandstones. Occasionally with pedogenic features.

Sh Well sorted very fine to medium sandstones with parallel lamination.

Sr Moderately well sorted very fine to fine or medium sandstones with current ripple lamination.

St Well sorted fine to very coarse sandstones with medium scale trough cross stratification. Sets are usually of 20-40 cm-thick.

Sp Well sorted fine to very coarse sandstones with medium scale tabular cross stratification. Sets are usually of 20-30 cm-thick.

Sd $\quad$ Cross-bedded sandstones showing evidence of deformation, such as overturned cross-beds, convolute stratification or dish structures.

Fine conglomerates with horizontal stratificacion forming thin and lenticular bodies. Sometimes with mud intraclasts.
Biostromes formed by the growing of a monospecific oyster community.

Mud-sand alternations are produced by fluctuation in the energy of the currents, which produce alternating traction and decantation processes, probably caused by tidally-modulated currents.

Decantation of fines in lentic environments or deposition of silt by tractive currents during floods. Desiccation cracks indicate subaerial exposure.

Deposition of silt to clay sized sediments in lentic environments or tractive silt deposits produced during floods.

Soil development in fine-grained sediments. Primary sedimentary structures obscured especially by root emplacement.

Tractive deposits that lost the primary sedimentary structures by pedogenic modification after deposition, or deposition by flows with elevated sediment concentration producing primary structureless deposits.

Subaqueous sedimentation during upper flow regime flows probably caused by unconfined flows in the floodplain.

Subaqueous sedimentation through migration of asymmetrical ripples during unidirectional lower flow regime tractive flows.

Subaqueous sedimentation produced by migration of dunes with sinuous crests under unidirectional currents

Subaqueous sedimentation produced by migration of dunes with straight crests under unidirectional currents.

Soft sediment deformation of sand deposits due to the friction of the overlying flow or sediment overloading.

Tractive currents forming longitudinal gravel bars in channel thalwegs. 


\subsubsection{Facies Association 1, coastal marine-terrestrial transition deposits}

The boundary between the terrestrial SCF and the underlying marine El Chacay Formation is not a sharp contact, as early noted by Feruglio (1938) and endorsed by Cuitiño et al. (2015); consequently, the location of this limit in the field is not straightforward. On the contrary, it is a stratigraphic interval having particular sedimentological features with a thickness of about $20 \mathrm{~m}$, which in this work is included into FA 1 . Thus, FA 1 includes both the upper part of the El Chacay Formation and the lowermost part of the SCF. From a strictly lithostratigraphic point of view, the boundary between the El Chacay Formation and the SCF in this area is placed in the uppermost level of the oyster Crassostrea orbignyi, same criteria used in former publications (e.g., Cuitiño et al., 2015).

This FA represents only the $5 \%$ of the section and is dominated by lithofacies $\mathrm{Ht}$, corresponding to a centimeter- to millimeter-thick alternation of sandstone, siltstone and mudstone layers (Fig. 3), arranged in lenticular, wavy or flaser bedding patterns (Reineck and Wunderlich, 1968). Sandstone and coarse siltstone layers usually reach up to $0.2 \mathrm{~m}$-thick and show current ripple (lithofacies $\mathrm{Sr}$ ) or parallel (lithofacies Sh) lamination. Occasionally, thicker sandstone beds, of up to $0.3 \mathrm{~m}$, show tabular cross bedding (lithofacies Sp), parallel lamination (lithofacies Sh) or are massive (lithofacies Sm). Bioturbation is scarce, only represented by isolated Planolites isp., Teichichnus isp. and Thalassinoides isp. Some outcrops of the area show the presence of lenticular, monospecific oyster accumulations (lithofacies B) intercalated within heterolithic deposit. These are formed by articulated or disarticulated Crassostrea orbignyi specimens (see Figure 5C of Cuitiño et al., 2015) and are interpreted as biostromes. In some layers, leaf or particulate vegetal remains where observed in muddy heterolithic sediments. In all outcrops visited, FA 1 grades transitionally upward to FA 2 (see below).

Interpretation: according to the abundance of heterolithic deposits, which suggest tidal modulated currents, the presence of oysters in life position (i.e., not transported), and the presence of some trace fossils of marine origin such as Teichichnus isp. and Thalassinoides isp., FA 1 is interpreted having marine influence, most probably a coastal marine to terrestrial transitional environment. Invertebrate-rich marine deposits, as those observed in underlying deposits (Cuitiño et al., 2015) are not observed in FA 1, suggesting stressing environmental conditions for marine life. Crassostrea orbigny beds were referred as estuarine organisms in the study area (Cuitiño et al., 2015) as well as in other parts of the Austral Basin (Griffin and Parras, 2012; Cuitiño et al., 2013), capable of thriving in low salinity estuarine water bodies (Cuitiño et al., 2013). The lack of coarsening upward meter-scale tabular sandstone deposits typical of beach or shorefaces sub-environments in this FA, suggest a protected coastal environment receiving low wave energy. Thin sandstone beds with tabular cross bedding $(\mathrm{Sp})$ may be explained by occasional unidirectional currents probably induced by tides within small tidal creeks.
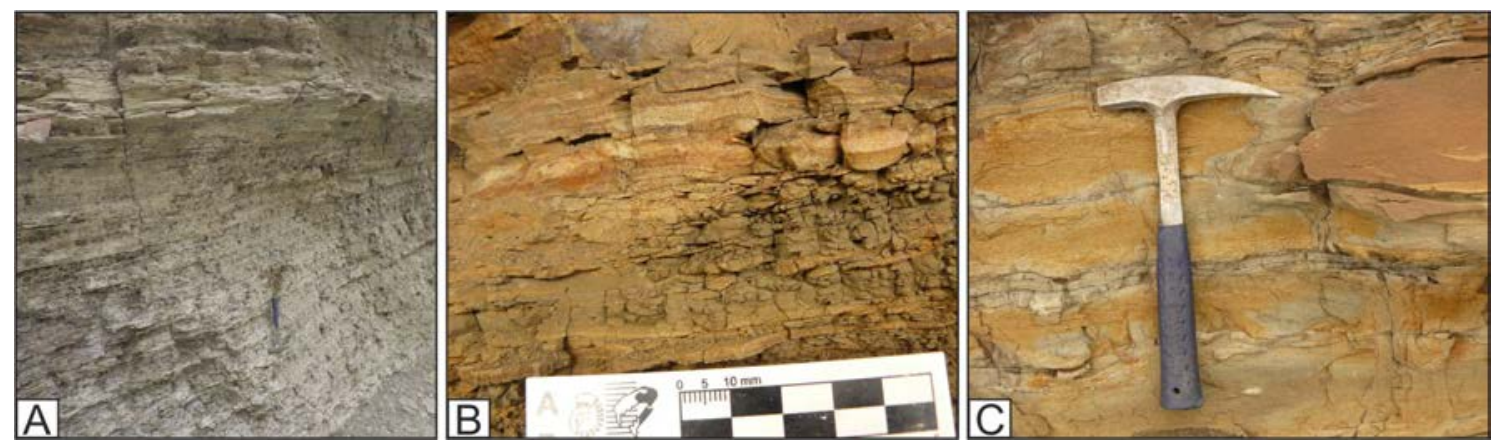

FIG. 3. Horizontal heterolithic deposits of FA 1. A. General view of this FA in which sandy layers (lithofacies Sh and Sr) project off the outcrop. To the top of the picture, a thicker cross-bedded sandstone bed (lithofacies St) is visible; B. Detail of muddy lenticular heterolithic deposits where millimeter- to centimeter-thick sandstone layers intercalate with mudstone layers. C. Detail of a sandy heterolithic (wavy+flaser) bedding. Note the lack of bioturbation or paleosol features in the three images. 
Some complementary paleoenvironmental interpretations for these deposits in association to others similar are described as the Facies D (estuarine complex) in Cuitiño et al. (2015).

\subsubsection{Facies Association 2, fluvial floodplain deposits}

Facies Association 2 represents the $65 \%$ of the stratigraphic thickness of the SCF in the studied section. This FA is dominated by structureless mudstones (lithofacies Fm) and mudstones with paleosol structures (lithofacies Fr), with minor millimeter-to centimeter-thick sandstone intercalations (Fig. 4). Those levels showing massive mudstones with no visible soil structures are referred as lithofacies Fm. Beds of FA 2 are tabular and vary in thickness from some decimeters to up $15 \mathrm{~m}$. Dark red hues are dominant for the mudstones although in some vertical cliffs, where floodplain mudstones are better

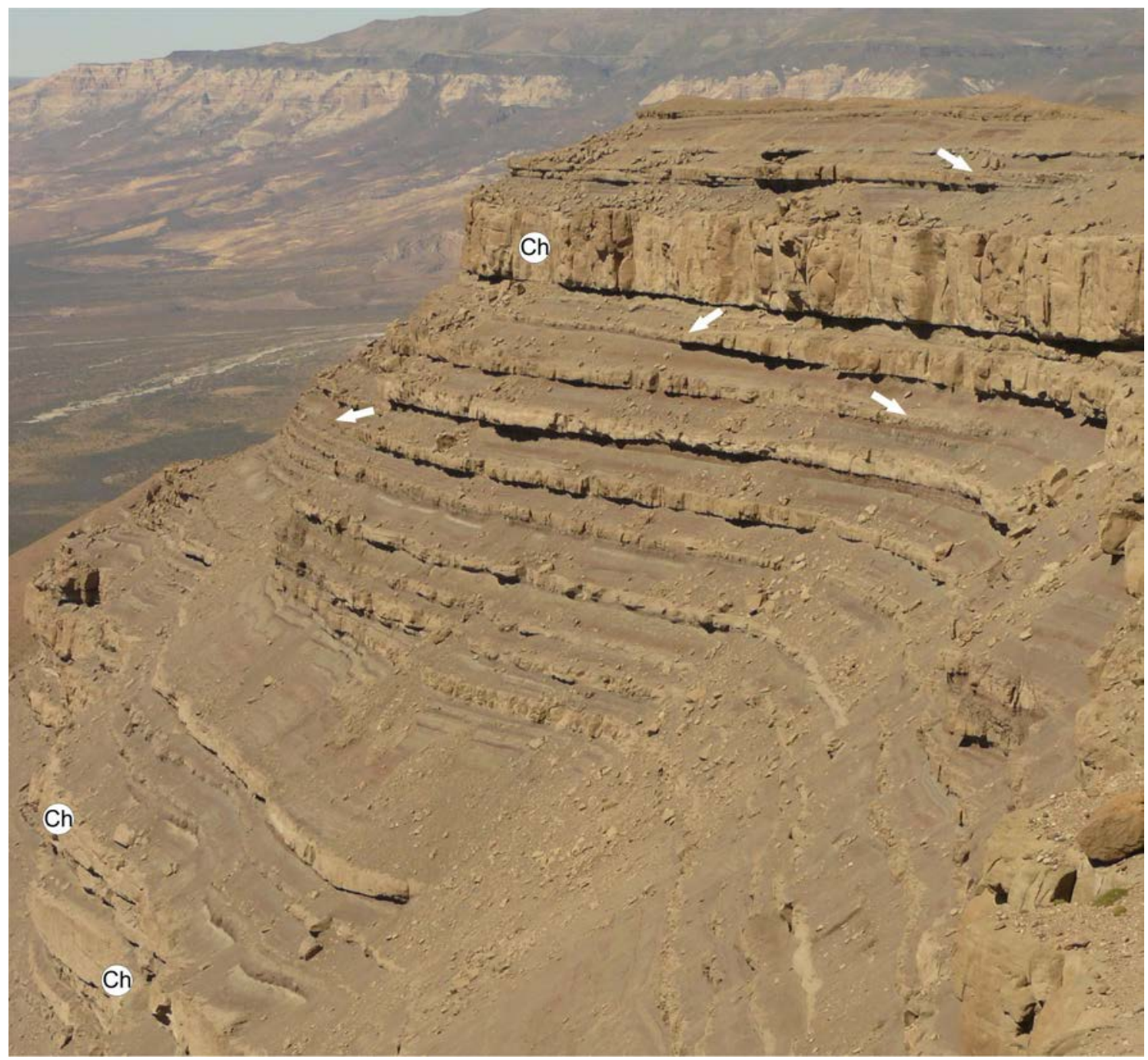

FIG. 4. Superb exposure (albeit inaccessible) of the lower to middle part of the SCF showing thick floodplain fluvial deposits (FA 2), composed of intercalated mudstone and thin sandstone beds. Changes in mudstone coloration from reddish to greenish suggest high frequency changes in oxidation conditions. Sandstone beds show sharp bases, sometimes erosive, and commonly wedge shape. White arrows point to evident wedging out of some of these beds. Few thicker, lenticular fluvial channels (Ch) also intercalate. In the background, the Río Tarde (whitish), the Posadas Basalt (dark grey) and the El Chacay (greenish) formations are observed. 
exposed, some centimeter to decimeter-thick greenish to gray layers are visible. Usually, these layers are composed of coarser (silt to fine sand) material and appear intercalated within mudstone intervals along the entire sedimentary section (Figs. 4 and 5A). Pedogenic structures such as small root traces (Fig. 5C), slickensides and blocky structures are commonly observed in the mudstones (lithofacies Fr). Excepting for the coloration changes, paleosol horizonation is hardly recognized, although caution on this observation has to be made due to the poor quality of many of the exposures of the fine-grained levels. Isolated or
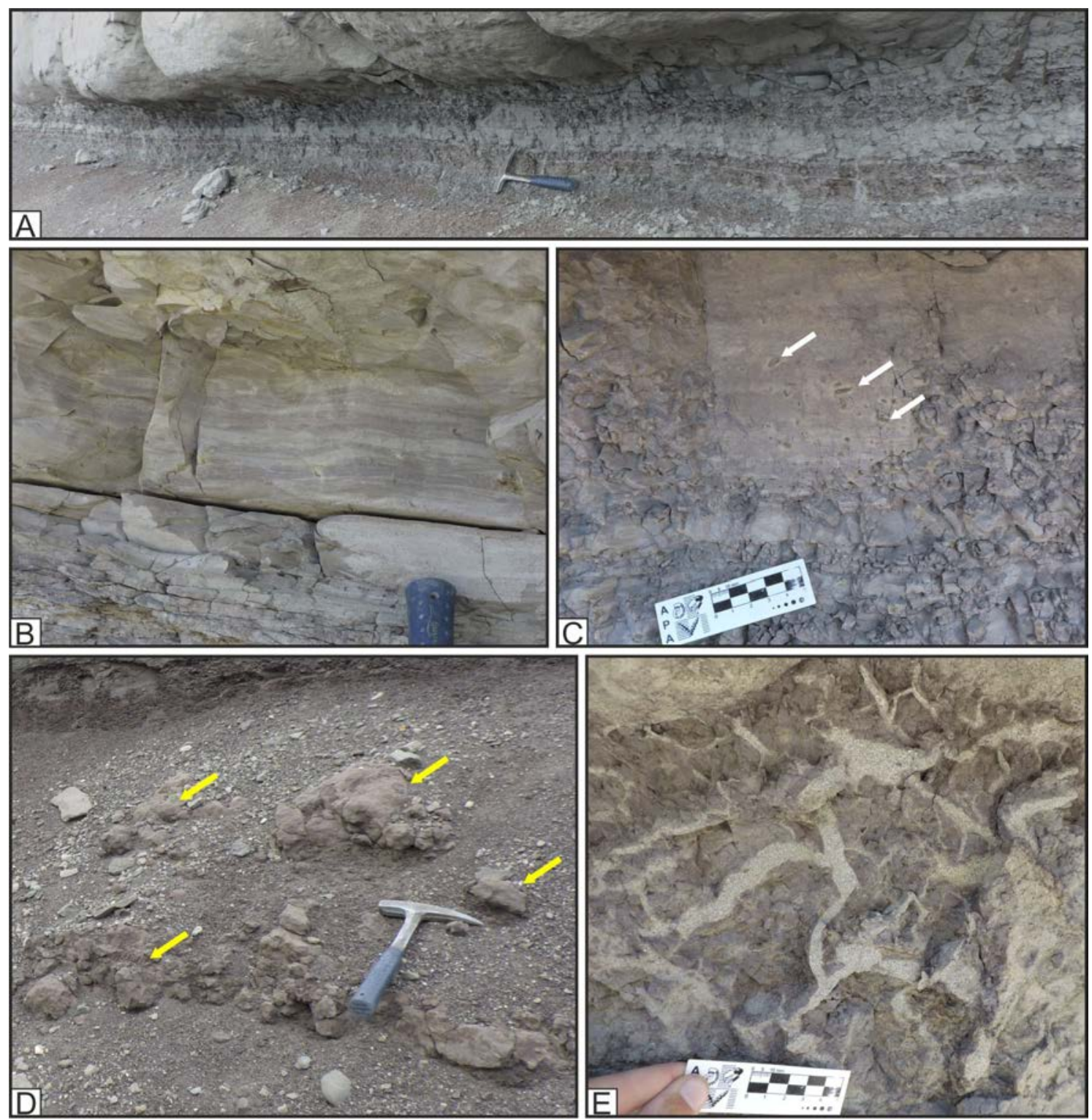

FIG. 5. Outcrop views of floodplain deposits of FA 2. A. Laminated thin fine sandstone (light color)/mudstone (dark reddish) intercalations interpreted as distal crevasse splay deposits, preserving tractive sedimentary structures. Covering the former with erosional contact are channel sandstones; B. Current ripple laminated sandstones and siltstones; C. Faintly laminated mudstones with root traces (arrows) showing light colored halos; D. Carbonate nodules (arrows) in massive reddish mudstones; E. Base of strata showing desiccation cracks filled with an overlying crevasse splay sandstone deposit. 
partially coalescent carbonate nodules are observed in several mudstone layers (Fig. 5D). In some occasions, they show tubular shape and vertical orientation and can be regarded as rhizocretions. Lamination in mudstones (lithofacies Fl) as well as ripple or horizontal bedding (lithofacies $\mathrm{Sr}$ and $\mathrm{Sh}$, respectively) are visible (Fig. 5A, B), although rare. Desiccation cracks are present occasionally (Fig. 5E), associated to laminated mudstones (lithofacies Fl). Tabular to wedge-shaped fine sandstone beds intercalate with mudstone deposits, ranging in thickness from a few centimeters to up to $0.8 \mathrm{~m}$. They show sharp bases, in some cases showing erosive features (Fig. 4) and internal parallel lamination (lithofacies Sh) or are structureless (lithofacies $\mathrm{Sm}$ ). In addition, some lenticular sandstone beds show planar base and convex-up top (Fig. 6) and internal structures such as planar cross-bedding (lithofacies $\mathrm{Sp}$ ) or parallel lamination (lithofacies Sh). Few small and isolated lenticular sandstone bodies with concave up base and planar top were also recognized.

Interpretation: the dominance of mudstones, either structureless or with paleosol structures, suggests deposition in a low-energy, low-gradient environment with frequent subaerial exposure where soils developed, typical of fluvial floodplains (Miall, 1996). Exposures of structureless mudstones (Fm) showing a weathered surface, pose some doubts about the recurrence of paleosol horizons. Well-exposed mudstone beds usually show some paleosol structures, suggesting these horizons are more common in the SCF than those observed. Dark reddish mudstone beds alternate with greenish to gray beds, suggesting cumulative paleosols which undergone periodic changes of oxygenation conditions (Krauss, 1999). Reddening of floodplain mudstones is usually referred as the consequence of well-drained conditions and rapid episodes of a fluctuating precipitation (Eren et al., 2015). Isolated carbonate nodules suggest weak development of calcretes, produced by precipitation of carbonate around small roots. This soil structure usually forms in semiarid to arid environments (Alonso-Zarza, 2003). Thin sandstone sheets with current ripple or parallel lamination indicate the action of tractive currents which can be interpreted as stages of flooding, producing unconfined flows on the floodplain (sheet floods). The interfingering of mudstone and sandstone beds sheets, wedges or lobeshaped fine sandstones with parallel lamination, and in some occasions with erosional bases, are interpreted as levees or crevasse splays deposits, produced after channel margin surpass during flood stages (Burns et al., 2017). These deposits imply fast sedimentation episodes, and in some occasions were associated to vertebrate fossil remains, suggesting fast burial of death organisms. The small and isolated channeled sandstones, intercalated within mudstone deposits, are interpreted as secondary channels crossing the floodplains, especially active during flood stages.

\subsubsection{Facies Association 3, fluvial channel deposits}

Facies Association 3 represents nearly $30 \%$ of the measured section and is mostly composed of lenticular or tabular bodies of trough cross-bedded sandstones

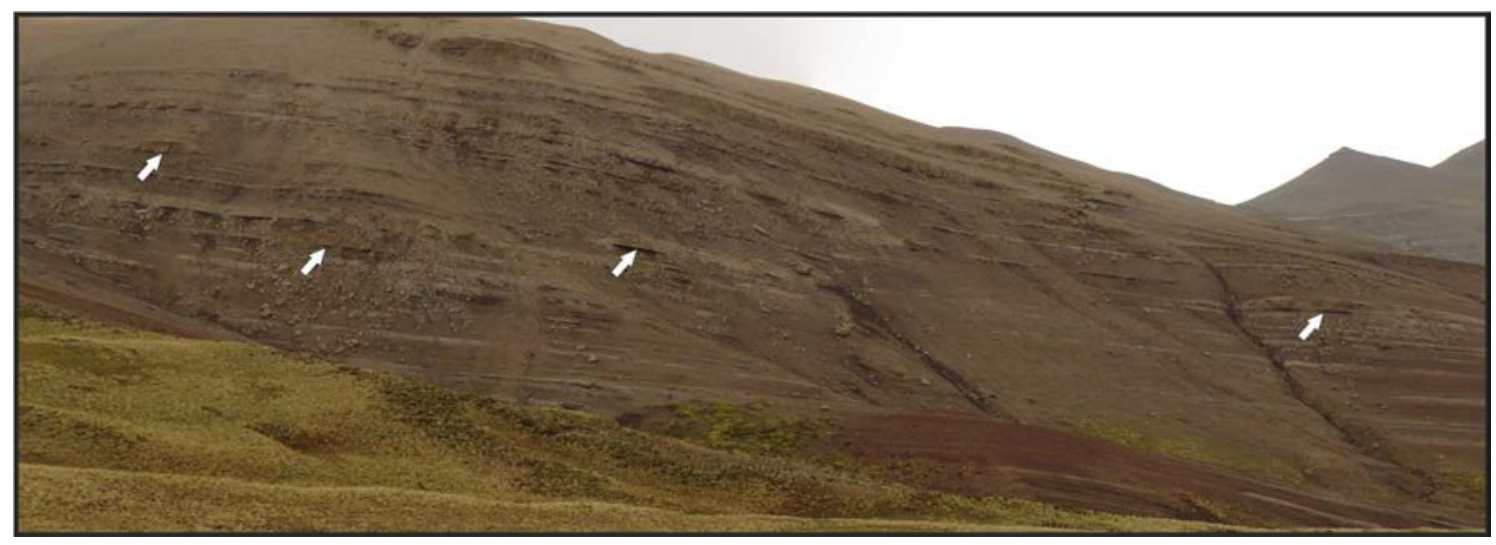

FIG. 6. View of the lower $30 \mathrm{~m}$ of strata of the SCF showing the dominance of dark reddish mudstones. Arrows highlight thin (less than $1 \mathrm{~m}$ ), lobate sandstone bodies interpreted as crevasse splay deposits. 
(lithofacies St) with a sharp base and homogenous grain size (Fig. 7A, B), although an internal finning upward trend is evident in some cases. Grain-size is typical medium to coarse sandstone at the base and may grade to fine sandstone at the top. Some minor thin pebble sandstones or fine conglomerates (lithofacies Gh) are present at the base of the beds (Fig. 7C). In some sandstone bodies, a thin lag of mudstone intraclasts is observed covering the bottom surface. Thicknesses of the sandstone bodies vary from 1 to $14 \mathrm{~m}$ although rarely exceed $3 \mathrm{~m}$. Internal major erosion surfaces are rarely observed in the channeled sandstones, although the thicker bodies show internal reactivation surfaces covered by thin layers of coarse-to-pebble sandstones. Sedimentary structures within these bodies are usually arranged as basal trough cross-bedded coarse sandstones (lithofacies St), followed by parallel
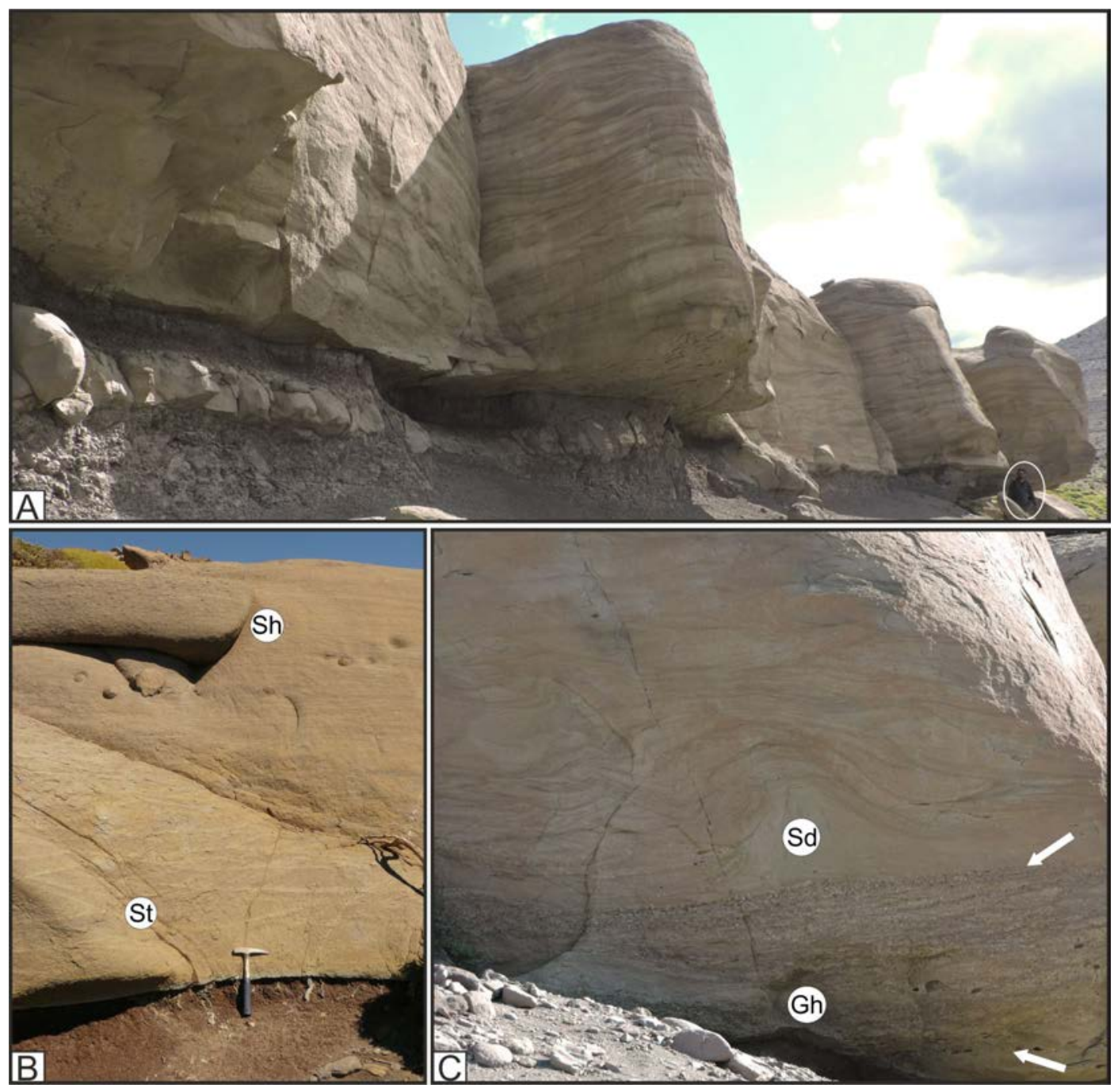

FIG. 7. Outcrop views of FA 3, fluvial channel deposits. A. A 4 m-thick sandstone channel deposit showing sharp, erosional base, cutting on floodplain deposits. Note internal homogeneous trough cross-bedding throughout the sandstone body. Person (circle) as scale; B. Channel sandstone (1.8 m-thick) showing sharp base over floodplain mudstones, internal grain-size gradation from medium to fine sandstone, and gradation from trough cross-bedding at the base (St) to horizontal lamination at the top (Sh); C. Channel deposits showing an intercalation of fine-conglomerates (lithofacies Gh) near the base (between arrows) and deformed trough cross-bedding (lithofacies Sd). The vertical distance between arrows is $0.7 \mathrm{~m}$. 
laminated (lithofacies Sh) or massive sandstones (lithofacies Sm), in turn covered by fine, massive sandstones (lithofacies $\mathrm{Sm}$ ) or siltstones (lithofacies Fm and Fr). In some occasions, when the lateral limit of a channel is well exposed, wings are observed wedging out into floodplain mudstones (see Figure 5E of Cuitiño et al., 2015). Measured width-to-thickness $(\mathrm{W} / \mathrm{T})$ ratios for the channeled sandstone bodies are in the range of 16 to 94 , although most fit between 20 and 50. Following Gibling (2006) these channels are classified as narrow sheets.

Interpretation: lenticular sandstone bodies intercalated between floodplain deposits of FA 2 are interpreted as fluvial channel deposits. The internal cross-bedded sandstones, the occasional finning upward trend and the erosive concave-up base are also indicative of channel deposition (Miall, 1985, 1996). Given the simple infill of the channels and the general reduced thickness of individual bodies, most are interpreted as shallow, single story channels. Internal erosion surfaces observed only for some thicker bodies, suggest reactivations of multistory channels. Channel amalgamation is rarely observed, and most are encased in floodplain deposits. The lack of lateral accretion evidence suggests these were fixed channels in a low sinuosity fluvial system (Miall, 1996; Gibling, 2006). These channels remain stable by levees reaching higher elevations than the adjacent floodplains. Figure $5 \mathrm{C}$ of Cuitiño et al. (2015) shows a channel margin in which vertically stacked wings wedge out into floodplain mudstones, indicating the channel remain stable in its position and levees allow the channel to reach an elevated position in relation to the floodplain. Deformed cross-stratified sandstone layers, occurring exclusively within channel bodies, are interpreted as produced by liquefaction of water-saturated sand triggered by overloading after fast sedimentation episodes in channels. This phenomenon may be the consequence of elevated sedimentation rates during high-discharge episodes.

\subsection{Paleocurrents and sandstone composition}

Thirty confident paleocurrent measurements were recorded from cross-bedded sandstones (lithofacies $\mathrm{St}$ and $\mathrm{Sp}$ ) representing channeled sandstones (FA 3). Measurements were recorded along the entire column of the SCF in Lago Posadas, taking care of measuring only on 3D exposures of the structures in order to obtain the true dune migration direction. Figure $8 \mathrm{~A}$ shows the distribution and proportion of measurement directions grouped into clusters of $30^{\circ}$ range. The mean paleocurrent direction is $93^{\circ}$ (i.e., to the east) and $76 \%$ of the paleocurrent measurements fall into the NE-SE (i.e., $\mathrm{N} 45^{\circ}$ to $\mathrm{N} 135^{\circ}$ ) interval, indicating a unidirectional pattern pointing roughly to the east. A minor (23\%) proportion of the measurements indicate paleocurrents toward the north and south.
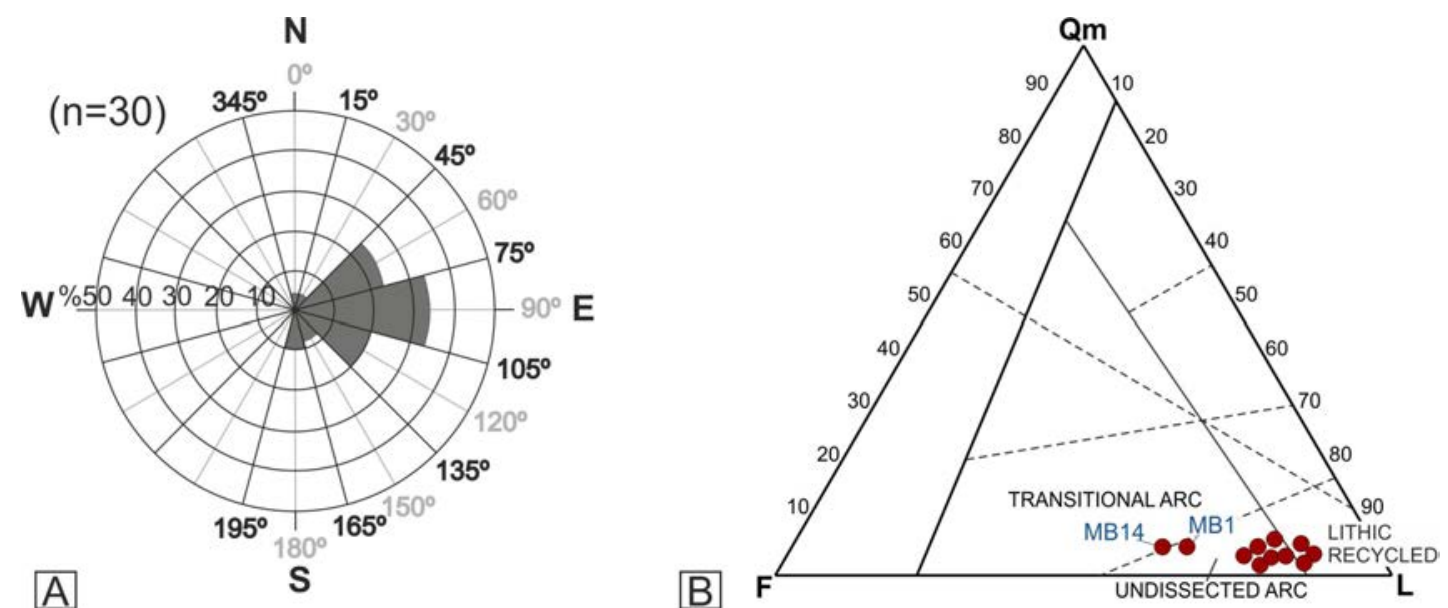

FIG. 8. A. Plot of data for paleocurrent measurements from channel cross-bedded sandstones. Note the clustering of vectors pointing mostly towards the east, as well as northeast and southeast; B. Dickinson et al. (1983) Qm-F-L provenance triangle. The overall reduced proportion of quartz is evident, and most of the samples plot close to the "lithic" apex (lithic recycled and undissected arc). 
All the sandstones analyzed in thin section are dominated by lithic particles and show low quartz proportion (all below 20\%). Most of the samples classify as litharenites excepting two samples that classify as feldspathic litharenites (samples MB1 and MB14), following Folk et al. (1970). Plotting the data into the tectonic provenance triangle of Dickinson et al. (1983) most of them cluster into the "undissected arc" field whereas three of them fall into the "lithic recycled" and one (MB14) into the "transitional arc" (Fig. 8B).

Lithic particles compose $60 \%$ to $85 \%$ of the grain fraction and are fairly dominated by volcanic particles, with minor proportions of low-grade metamorphic grains and very few sedimentary and plutonic grains. Particles of primary pyroclastic origin are virtually absent. Feldspar particles usually compose less than $20 \%$ of the population, with only two samples above $30 \%$ (Fig. 8B). They are represented by plagioclase as the dominant component. Two samples (those classified as feldspathic litharenites) show higher proportion of plagioclase.

Accessory minerals include micas (biotite and muscovite), amphiboles, pyroxenes and opaques. The predominant cement is zeolitic and in some cases carbonate with a pervasive alteration of the clastic components. Occasionally, clay rim (illitesmectite series) cement is developed surrounding the grains.

\subsection{Vertical stratigraphic trends}

The measured section of the SCF south of Lago Posadas is $460 \mathrm{~m}$-thick and shows a general homogeneous vertical facies composition (Fig. 9). The base of the unit is transitional with the underlying marine to estuarine deposits of the El Chacay Formation (Cuitiño et al., 2015), whereas the top in this area is truncated by an erosional unconformity and is covered by modern gravel deposits.

Despite its homogeneity, some slight variations can be recognized along the SCF column. Sandstone/ mudstone proportion along the measured column is essentially constant, although a slightly higher proportion of mudstone deposits is recognized in the lower $30 \mathrm{~m}$ of the unit, immediately above the transition with estuarine deposits (Fig. 6). This lower muddy interval shows a distinctive dark reddish coloration, which is visible and correlatable along several sites in the region, especially with the Jeinimeni
Formation at the Zeballos-Jeinimeni Rivers to the north. In addition, this lower portion shows a higher frequency of paleosol horizons in floodplain deposits, and also shows a higher proportion of lobe-shaped sandstone bodies (Fig. 6). Upward in the column, a change of the dominant coloration is recognized with dominance of gray colors in the upper part.

Besides the sandstone/mudstone proportion, the thickness of individual sandstone beds shows slight vertical stratigraphic variations. The lower $100 \mathrm{~m}$ of the unit shows sandstone beds rarely overcoming 3 m-thick (Fig. 6), whereas from $100 \mathrm{~m}$ upwards, thicker sandstone beds ( 4 to $5 \mathrm{~m}$-thick) are more common (e.g., Fig. 7A), reaching to a maximum of $14 \mathrm{~m}$-thick (Fig. 9). The middle and upper portions of the SCF studied herein are lithologically correlatable with equivalent strata to the north assigned to the Cerro Boleadoras Formation.

Grain-size trends are hardly recognized in the measured column. When considering the sandstone beds alone, a dominance of medium sandstone is observable throughout the column. Coarse sandstones and thin lags composed of granule or fine conglomerates are more common from $100 \mathrm{~m}$ upward. Only one channeled sandstone bed shows a relatively thick (up to $1 \mathrm{~m}$ ) fine conglomerate (lithofacies Gh) interval at the base (Fig. 7C).

No vertical trends in paleocurrent direction neither in sandstone composition are recognized for the SCF in this locality. Given the lack of major compositional modal variations in the analyzed sandstones along the section, one single petrofacies is defined for the $\mathrm{SCF}$ in this site.

\subsection{Vertebrate paleontology}

The paleontological prospection was focused in the hills that are immediately southwest of the cliff that limits the plateau, southwest of Lago Posadas (Fig. 1). These hills expose the SCF, and are part of the areas prospected by Hatcher (Fig. 2) and correspond to the site where Blisniuk et al. (2005) measured their stratigraphic section. The vertebrate fossil collection is composed of 23 specimens of mammals. The material is fragmentary and was recovered loose on the surface, except for two specimens that were found in situ (the toxodonts Homalodotherium and Nesodon). Most of them come from the lower to mid-levels of the stratigraphic column (Fig. 9). 

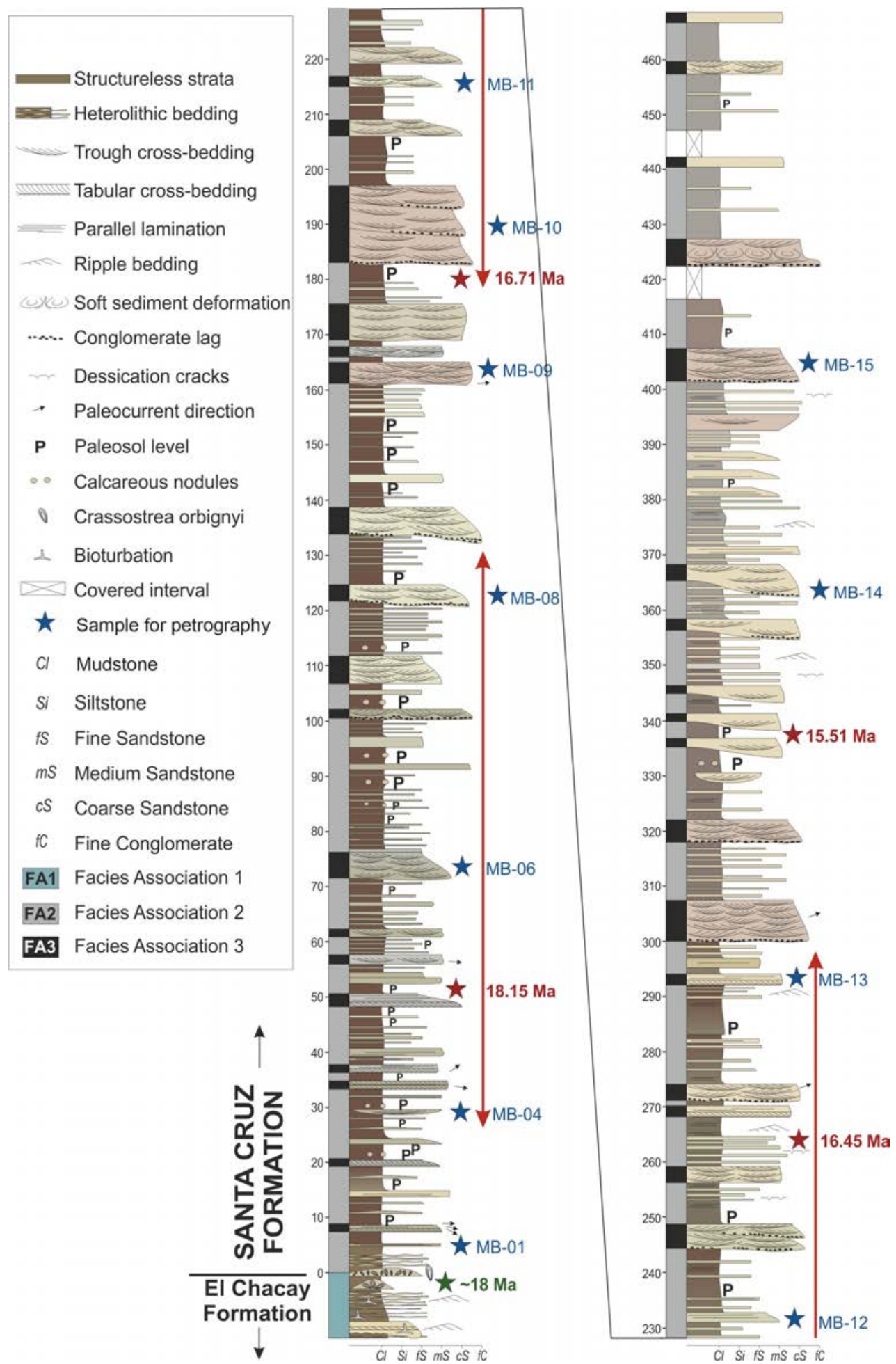

FIG. 9. Vertical stratigraphic section measured for the SCF south of Lago Posadas (see location in Fig. 1). Blue stars indicate the position of the samples taken for thin section analysis. The position of numerical ages from Cuitiño et al. (2015) (green stars) and Blisniuk et al. (2005) (red stars) are indicated. Vertical red arrows indicate the stratigraphic position where fossils were collected. 
The specimens recovered by Hatcher's expeditions for the Princeton University (currently at YPM), total about 50 specimens sourced from the same general area where we worked, and include some articulated specimens in nodules (Fig. 10A). The specimens collected by Brown for the AMNH are fewer than Hatcher's. In an unpublished report to the AMNH, Brown stated that he collected remains of four typotheres. These specimens do not appear in the catalogue of the Vertebrate Paleontology Department, but there are four unprepared specimens in the collection with original handwritten cards that indicate their provenance from "Lake Pueyrredon". Furthermore, the sediment matrix is composed of medium to coarse sandstones that clearly resembles rocks of the SCF in Lago Posadas (Fig. 10B). Particularly, the sediment matrix of some specimens is similar to that of the sheet sandstone beds of the FA 2, and also similar to the sediment matrix of the few specimens found in situ by us. A collection of about 20 specimens from Lago Posadas is housed in the MLP (Argentina), of which only 12 were identified. Albeit fragmentary, the material is in an acceptable state of preservation making their identification possible. The exact stratigraphic provenance of this material is not confidently established.

The complete list of specimens (collected in the field and housed in museums) from Lago Posadas and Pueyrredón, with catalogue numbers and information about the materials, collectors and provenance is provided in Appendix 1.

The faunal assemblage of the Lago Posadas area includes 31 taxa: 28 mammals and three birds (see Table 2; Fig. 11). Due to the poor quality of some specimens and/or the lack of recent systematics revision, they could be identified only at a high taxonomic level. Mammals belong to the main groups recorded in other areas of the SCF (metatherians, xenarthrans, notoungulates, litopterns, astrapotheres and rodents).

\subsection{Paleoecological analysis}

The paleoecological analysis was based on body mass, diet and substrate preference and use. Results are displayed in table 2, which includes categories for these biological attributes following Kay et al. (2012).

Most mammals recorded fall in body mass categories III and IV (19 taxa between one and $100 \mathrm{~kg}$ ). Category I (10-100 grams) is not represented. The only mammal certainly smaller than one kilogram (II) is the rodent Perimys. About one third (nine) of the taxa fall within category III $(1-10 \mathrm{~kg})$ : one marsupial, one armadillo, all typotheres, and two rodents. Another third (10 taxa) fall within category IV (10-100 kg): one armadillo, glyptodonts, most sloths and proterotheriid litopterns. The remaining third fall in categories V (100-500 kg) and VI ( $>500 \mathrm{~kg})$.
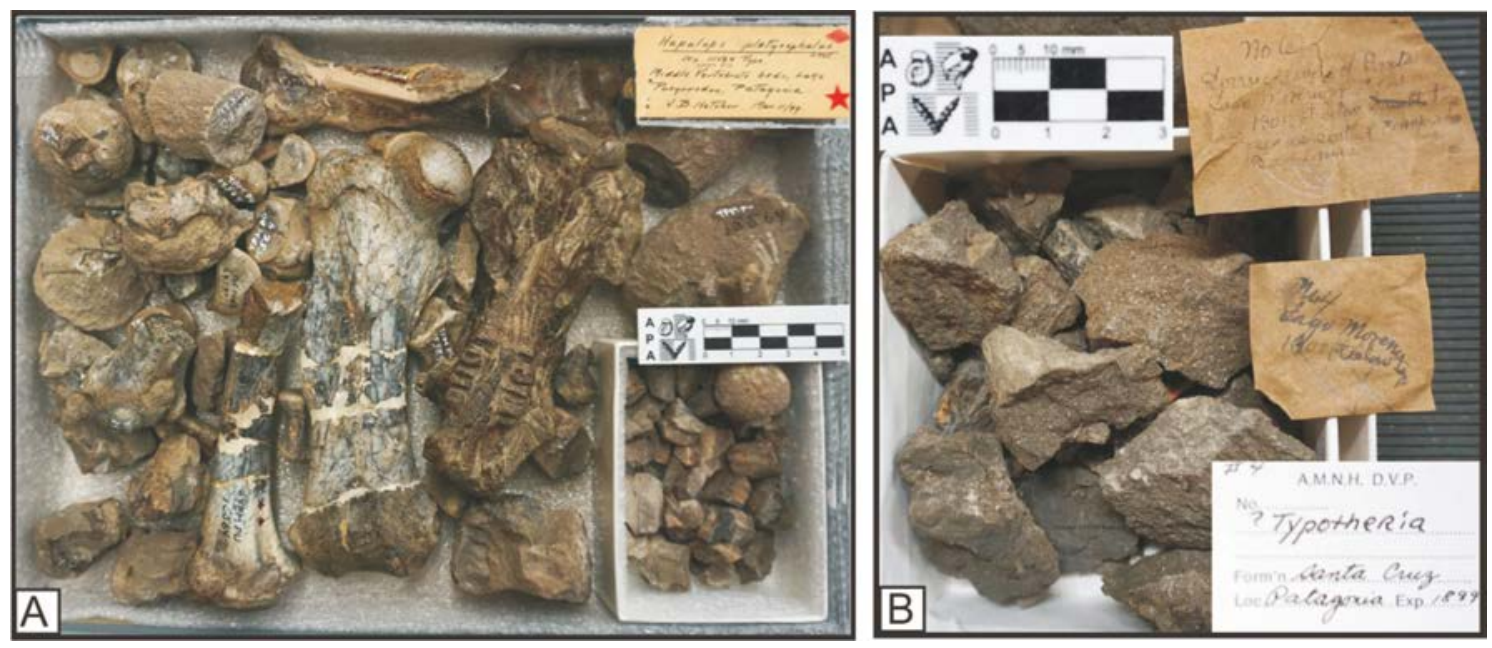

FIG. 10. Some fossils from Lago Posadas collected by J.B. Hatcher and B. Brown. A. YPM-VPPU 15564. The sloth Hapalops platycephalus (Holotype). B. AMNH w/n. A typothere from Lake Pueyrredón, unprepared. 
TABLE 2. TAXA RECORDED IN THE SCF AT LAGOS POSADAS AND PUEYRREDÓN, AFTER A PRELIMINARY REVISION, WITH INFERENCES ON THEIR MAIN PALEOBIOLOGICAL ATTRIBUTES. THE LIST INCLUDES TAXA COLLECTED DURING OUR FIELD SEASONS, AND THOSE RECORDED IN THE MUSEUM'S COLLECTIONS (SEE APPENDIX 1).

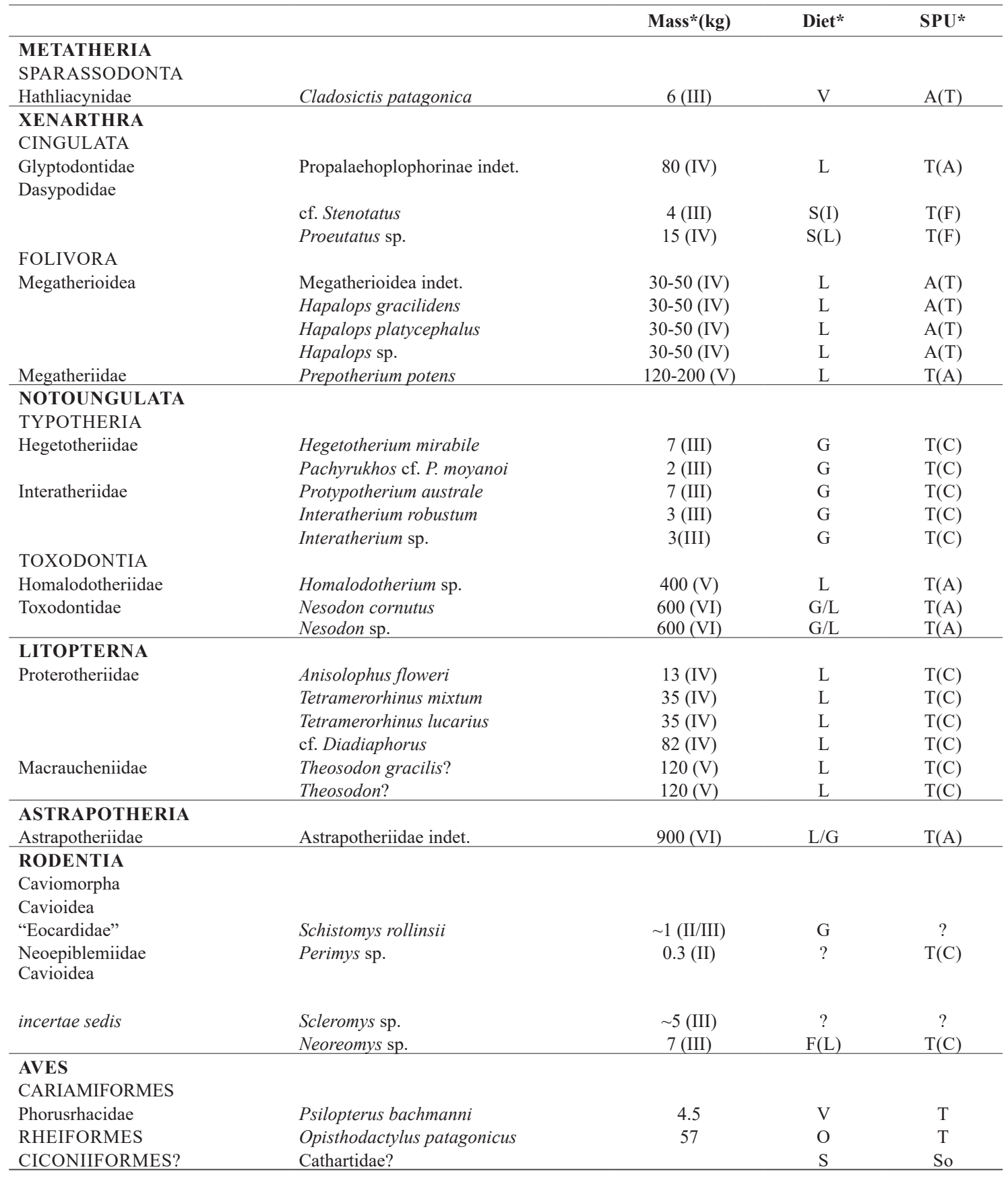

* Categories of biological attributes. Mammals, based on Kay et al. (2012). Body mass: II, 100 g to $1 \mathrm{~kg}$; III, 1 to $10 \mathrm{~kg}$; IV, 10 to $100 \mathrm{~kg}$; V, 100 to $500 \mathrm{~kg} ; \mathbf{V I},>500 \mathrm{~kg}$. Diet: V, vertebrate prey; S(I), scavenging and insects; $\mathbf{S}(\mathbf{L})$, scavenging and browse; $\mathbf{F}(\mathbf{L})$, fruit with leaves; L, leaves (=dicot leaves, buds shoots); G, grass stems and leaves (graze). SPU (Substrate Preference and Use): A(T), arboreal and terrestrial (scansorial); T(A), terrestrial and ambulatory; T(C), terrestrial and cursorial; T(F), terrestrial and fossorial. Birds, based on Degrange et al. (2012). Diet: Inv/V, Invertebrates and small vertebrates; O, omnivorous; S, scavenging. SPU: T, terrestrial; So, soaring. 

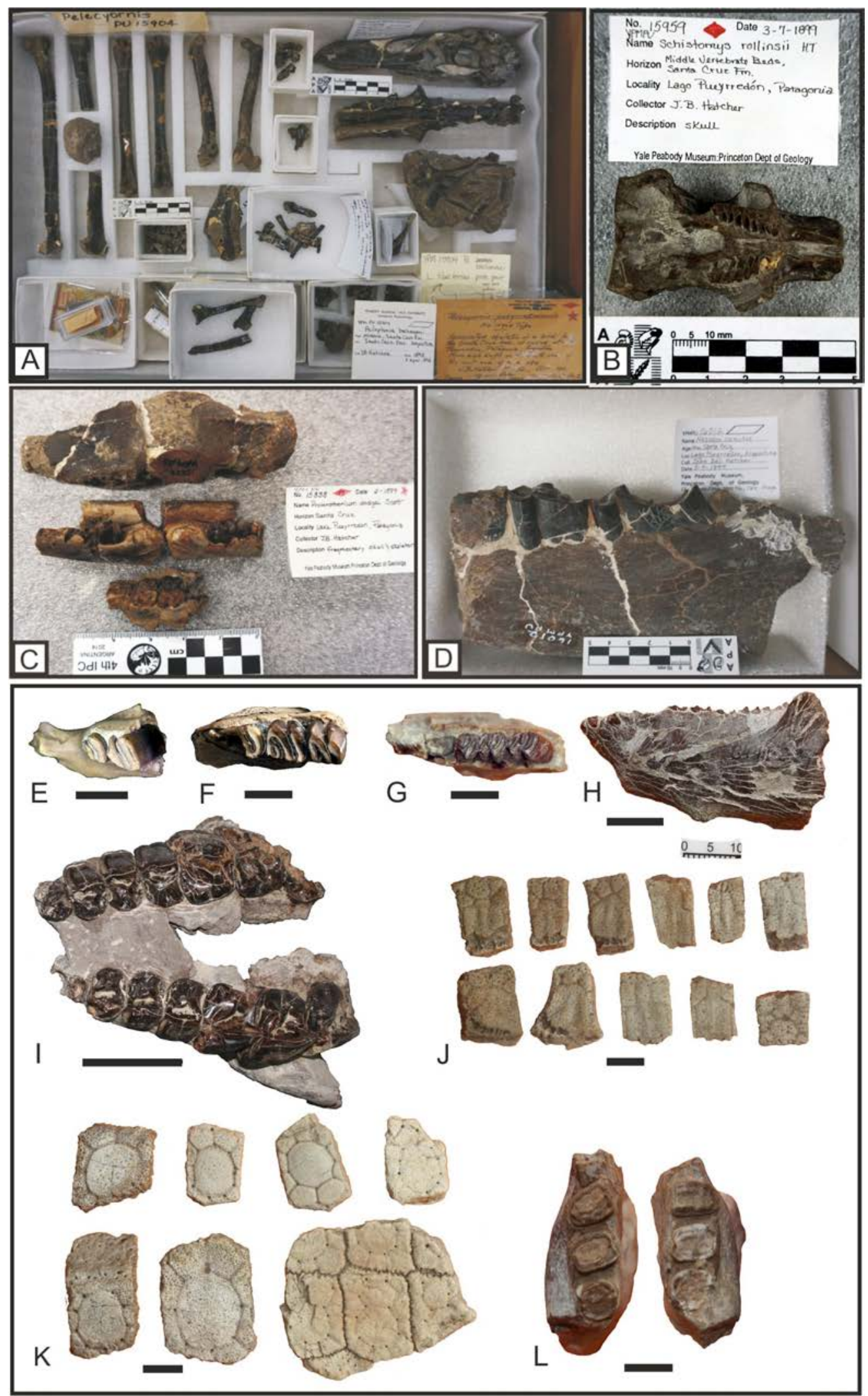
Category V includes one sloth, the homalodotheriid toxodont and the macraucheniid litoptern; category VI the toxodontid and the astrapothere. The largest taxa are the notoungulates Homalodotherium $(400 \mathrm{~kg})$ and Nesodon $(600 \mathrm{~kg})$ and one astrapothere $(900 \mathrm{~kg})$.

Among herbivorous mammals, grazers are represented by one rodent (Schistomys) of about one kilogram, four genera of typotheres of less than ten kilograms and one toxodontid (mixed-feeder) of about $600 \mathrm{~kg}$. Browsers are represented by one genus of a mostly arboreal sloth (Hapalops) that ranged between 30 and $50 \mathrm{~kg}$, and a more terrestrial megatheriid sloth of about 120-200 kg, four genera of litopterns between 10 and $120 \mathrm{~kg}$, a $400 \mathrm{~kg}$ homalodotheriid and an almost one-ton astrapotheriid. The only proposed frugivore is the seven-kilogram rodent Neoreomys. There are not specialized seed feeders. There are no strict arboreal taxa suchs microbiotheres, porcupines, and primates.

The carnivore guild is represented only by one hathliacynid metathere, of about six kilograms and mainly arboreal. Scavengers are represented by two armadillos between one and $15 \mathrm{~kg}$. There are not strict insectivorous neither specialized myrmecophagous.

Among birds there is one omnivorous rhea of about $50 \mathrm{~kg}$, one small predatory phorusrhacid of about $5 \mathrm{~kg}$, and one scavenging New World vulture.

\section{Discussion}

\subsection{Depositional environments and temporal stratigraphic changes}

The SCF south of Lago Posadas is composed of an alternation of mudstone and sandstone beds, rich in terrestrial vertebrate remains, being the mudstones the dominant deposits.

The base of the SCF in Lago Posadas is not a sharp surface but a transition interval of about
20 m-thick composed of estuarine fine-grained deposits (Cuitiño et al., 2015). Small biostromes formed by the oyster Crassostrea obignyi are a distinctive element within this interval. Since no distinctive boundary between the SFC and other underlying marine deposits is present, these oysters where used in other localities as marker horizons (Griffin and Parras, 2012; Cuitiño et al., 2013; Cuitiño et al., 2015). This interval represents the passage from fully marine-estuarine to terrestrial deposits without any major temporal gap. This is supported by the lack of major physical discontinuities, as well as by the existing geochronological data (Blisniuk et al., 2005; Perkins et al., 2012; Cuitiño et al., 2015) which shows no significant temporal gaps throughout the Miocene sedimentary column of Lago Posadas. The fluvial system of the SCF prograded into a shallow marine embayment that occupied a large NW-SE trough (Windhausen, 1924; Malumián and Náñez, 2011; Cuitiño et al., 2015), comprising the northern extreme of the Austral Basin and named as the Posadas Sub-Basin (Bellosi, 1995). The transitional passage from marine to terrestrial deposits allows describing this interval as a normal regression, part of a Highstand Systems Tract (Catuneanu, 2006).

Facies analysis for the overlying terrestrial portion of the SCF indicates that the whole unit was deposited by a low-gradient fluvial system that developed extensive fine-grained floodplains, crossed by sand-bed fluvial channels. Conglomerates are nearly absent in the system, only forming thin lags or lenticular bodies at the base of the larger channel deposits. The overall fine-grained nature of the fluvial system represented by the SCF in Lago Posadas, and the lack of thick conglomerate deposits typical of settings located close to mountain ranges (e.g., gravel-bed braided fluvial systems or alluvial fans, Miall, 1996), suggests the analyzed section of the SCF was located in a distal position in relation

FIG. 11. Vertebrate specimens from Lago Posadas; some from the old collections at YPM and MLP, and new specimens collected by SFV, that belong to the MPM (Río Gallegos, Santa Cruz Province, Argentina). A. The phorusrhacid Psilopterus bachmanni $($ YPM-VPPU 15904)=Pelecyornis pueyrredonensis $($ Holotype); B. The cavioid rodent Schistomys rollinsii (YPM-VPPU 15959 (Holotype); C. The litoptern Tetramerorhinus mixtum (YPM-VPPU 15838)=Proterotherium dodgei (Holotype); D. The toxodontid Nesodon cornutus (YPM-VPPU 16012, Holotype); E., F. and G. The rodents Perimys sp. (MLP 84-III-2-40) and Scleromys sp. (MLP 84-III-2-9), scale bar=0.5 cm, and Neoreomys sp. (MPM-PV 17471), scale bar=1 cm; H. The typothere Interatherium $\mathrm{sp}$. (MLP 84-III-2-32), scale bar=1 cm; I. The toxodontid Homalodotherium sp. (MPM-PV 17474), scale bar=5 cm; J. The dasypodid armadillo Proeutatus sp. (MPM-PV 17465), scale bar=1 cm; K. A Propalaehoplophorinae glyptodont (MPM-PV 17472), scale bar=1 cm; L. A megatherioid sloth cf. Hapalops sp. (MPM-PV 17460), scale bar=1 cm. 
to the (Miocene) Andean orographic front. We hypothesize that because of high subsidence rates, the gravel sediments originated in proximal areas was retained in alluvial fans located at the foot of the early Miocene Andes, west of the study area, which were subsequently eroded by eastward migration of the deformational front (Fosdick et al., 2013; Ghiglione et al., 2016a, b) and finally not preserved in the study area. Following this idea, only the fine sediments (mud and sand) surpassed the alluvial fans and arrived to the adjacent eastern plains.

Fine-grained, floodplain-dominated fluvial systems are often referred as High Accommodation Systems Tract (Shanley and McCabe, 1994; Catuneanu, 2006). The SCF in Lago Posadas shows several features similar to those systems, such as channel deposits encased in floodplain mudstones, poorlydeveloped paleosols, large thicknesses and low sand/mud ratios (Catuneanu, 2006). Additionally, fine-grained, floodplain-dominated fluvial systems lacking evidences for lateral migration of channels, combined with low to medium (10 to 100) widthto-thickness (W/T) ratios for channel bodies, are regarded as formed by anastomosed rivers (Miall, 1996; Makaske, 2001). These systems have fixed channels that change positions through avulsions producing abundant crevasse splays deposits, as observed in the SCF in Lago Posadas. One of the main limiting agents for lateral channel migration observed in modern anastomosed rivers is floodplain stabilization by vegetation (Makaske, 2001). Although immature, the recurrent paleosol horizons may account for this vegetation growth and channel margins stabilization. This is particularly more evident for the lower third of the SCF, where paleosol horizons appear more frequently. River anastomosis can be considered as the consequence of upstream or downstream control. Modern examples suggest that sediment overloading of fluvial systems (upstream control) entering a low gradient foreland area may be the cause of anastomosis (Makaske et al., 2017). However, the long term anastomosing fluvial architecture can be achieved if the basin is constantly subsiding.

Dark reddish floodplain deposits (e.g., Fig. 6) suggest oxygenated environments with low proportion of preserved organic matter. The low organic matter content, plus the absence of any micro or macrofossil plant remains, indicates fast oxidation of organic matter after deposition. Abundant paleosol structures, including carbonate nodules, slickensides, soil peds and root traces, suggest recurrent paleosol formation (Retallack, 2001). However, paleosol horizonation is hardly recognized, suggesting poor soil development (inceptisols). Each poorly developed paleosol represents relatively short periods of landscape stability. The lack of well-developed paleosol horizons, the abundance of crevasse splay deposits and the floodplain-dominance in the whole fluvial system, suggest overall continuous aggradation under moderate to high sedimentation rates. These rates however, seem to have been relatively slower for the lower third of the unit where paleosols appear in a higher frequency. This is in agreement with the sedimentation rates calculated by means of geochronologic data by Blisniuk et al. (2005) for this locality.

From a paleoclimatic point of view, carbonate nodules (rhizocretions) indicate arid to semiarid conditions (Alonso-Zarza, 2003), which is in agreement with previous estimations for this locality (Blisniuk et al., 2005). Raigemborn et al. (2018) showed similar features for the SCF in the southeast of the Santa Cruz Province, interpreted as fluctuations of wetter and dryer paleoclimatic conditions at different temporal hierarchies.

Paleocurrent data indicate the fluvial system that the SCF represents drained towards the east (Fig. 8). Thus, the origin of the sediments most probably was the Southern Patagonian Andes. Sandstone composition shows a clear dominance of volcanic lithic particles. The lack of fresh, primary volcaniclastic particles (e.g., shards, pumice) in sandstones suggest their origin is through weathering and erosion of ancient volcanic rocks. West of the study area the Southern Patagonian Andes show abundant exposures of the Jurassic El Quemado Complex volcanic and volcaniclastic rocks (Fig. 1), which can be considered as the most probably source for the SCF sandstones, albeit other minor sources cannot be discarded.

Vertical stratigraphic changes in the SCF of Lago Posadas are subtle, and no easily recognized. Paleocurrent directions and sandstone composition show slight changes although without significant trends, suggesting the source of sediments for this sedimentary system remained the same. However, the detailed field observations of lithofacies and stacking patterns allowed pointing some slight stratigraphic trends. From base to top, the $460 \mathrm{~m}$ of terrestrial sediments show a slight increase in the ratio of sandstone/mudstone, as well as an increase 
in channel deposits grain-size and thickness (Fig. 9). The lower $100 \mathrm{~m}$ of the SCF show dominance of floodplain mudstones and sandstones with few channel deposits (Fig. 6). Coarse sandstone deposits are only present, although never dominant, in the upper part of the SCF, indicating a slight progradation of the sedimentary system. However, the mudstone/ sandstone ratio remains essentially the same for the whole column, suggesting the accommodation space was uniform through time during the deposition of the unit. All these evidences allows defining the entire depositional system of the SCF as a High Accommodation Systems Tract (Catuneanu, 2006), although the vertical changes described points to a subtle upward lowering of accommodation.

An additional slight vertical trend is recognized within the floodplain mudstones. Paleosol horizons are relatively more abundant in the lower third of the unit. Although color variations can be observed at a high frequency (decimeters to meters, e.g., Fig. 4), a change of the dominant coloration is recognized along the column, from dark reddish-dominated at the lower third, to gray-dominated at the upper part. Primary sedimentary structures, such as lamination and ripple lamination are more common in floodplain deposits to the upper part, which is also associated to a low proportion of pedogenically modified levels. The cause of this better preservation of primary structures in the floodplain deposits of the upper part of the section can be associated to a lack or a weak paleosol development (Krauss, 1999; Retallack, 2001). This can be associated to recurrent episodes of high sedimentation rates in the floodplain for the upper two thirds of the SCF. Higher upward, sedimentation rates seem to be in contradiction to the upward reduction of accommodation suggested above. Thus, it is likely that these subtle changes observed for floodplain mudstones could be the consequence of the prevalence of sedimentary processes occurring at fast velocity, such as flash floods. Alternatively, this can be explained through a reduction of the velocity at which pedogenic processes occur, probably controlled by colder and/ or dryer climatic conditions. Geochronologic data provided by Blisniuk et al. (2005) indicates low sediment accumulation rates in the lower part and relatively high rates in the upper part of the SCF. This differential accumulation rates can explain the relatively higher abundance of paleosol horizons to the lower part of the unit.
Based on stable isotopes from calcareous paleosol nodules, Blisniuk et al. (2005) detected a trend to more arid environments upward in the SFC column of Lago Posadas. They interpreted a major ecosystem change at $\sim 16.5 \mathrm{Ma}$, which is roughly at the half of the column of the SCF. This means a climate change that could have been produced by the growth of the Andes and the subsequent instauration of the rain shadow effect in the foreland area. Similar conclusions, based mainly on sedimentological attributes, were obtained by Tauber (1999) for the exposures of the unit in the southeastern region of Santa Cruz Province (i.e., roughly $450 \mathrm{~km}$ southeastward), suggesting this climatic deterioration could be a regional phenomenon. This isotope-based proposed climate change is roughly recognized in the sedimentary facies of the $\mathrm{SCF}$ at Lago Posadas. Only some color changes in floodplain mudstones and frequency of paleosols can be observed, although these features could be explained through differential depositional rates. Whether these changes were controlled by climatic effects is somewhat uncertain. This implies that the proposed climate change had a minor effect on the fluvial depositional style, which remains essentially the same for the entire SCF in Lago Posadas.

The top of the SCF in the exposures studied south of Lago Posadas is truncated by modern glacio-fluvial deposits that form a flat terrace. Farther south, close to the central part of the Meseta Belgrano and at higher elevations, the unit is covered by the Belgrano Basalt (Fig. 1).

\subsection{The SCF of Lago Posadas in a basinal correlation context}

The terrestrial sediments that compose the SCF (and equivalents) are recognized in a huge area of southern Patagonia, particularly well-recorded in the Austral Basin. Several nomenclature proposals exist, and it is not the objective of this work to discuss the formal terminological issue.

North of the study area, two main regions expose early Miocene sediments equivalent to those described here. In the northern extreme the early Miocene fluvial deposits of the Pampa Guadal and Meseta Cosmelli of the Aysén Region of Chile, referred as the Galeras Formation or SCF (Niemeyer et al., 1984; Flint et al., 1994; Flynn et al., 2002; De la Cruz and Suárez, 2006; Bostelmann and Buldrini, 2012). Recently, Ugalde et al. (2015) defined these deposits 
as the SCF, which were interpreted as low to moderate energy fluvial deposits, suggesting temporal and paleoenvironmental equivalence to the SCF of Lago Posadas. Fossil mammals of Santacrucian times (Flynn et al., 2002) also confirms this timecorrelation to that area.

About 50 to $100 \mathrm{~km}$ north of Lago Posadas and south of Lago Buenos Aires in the Santa Cruz province of Argentina, a thick column of terrestrial early Miocene strata is grouped as the Río Zeballos Group (Ugarte, 1956). From base to top the Río Jeinimeni, Cerro Boleadoras and Río Correntoso formations are defined (Ugarte, 1956), forming a clear coarsening up succession of approximately 1,000 m-thick (Escosteguy et al., 2003). Based on facies similarity, the mudstone-dominated lower part of the SCF at Lago Posadas can be correlated with the Río Jeinimeni Formation, whereas the sandier upper part of the SCF can be correlated to part of the Cerro Boleadoras Formation. Similar grain-size trends are also described for the SCF in Meseta Cosmelli (De la Cruz and Suárez, 2006; Ugalde et al., 2015), a large but isolated outcrop area in the Aysén region (Chile) that show remarkable stratigraphic similarities with the Argentinean exposures. The sand-dominated part of the Cerro Boleadoras Formation and the conglomeratic Río Correntoso Formation (Ugarte, 1956) both have no equivalent in our studied section of the SCF. Fossil mammal descriptions from these beds are nearly absent. Based on the record of certain anteater and rodents taxa, Carlini et al. (1993) and Vucetich (1994) indicated a Santacrucian ages for the Cerro Boleadoras Formation. The Río Zeballos Group suggests the proximal depositional systems appear to have moved eastward into the foreland basin as a response to eastward migration of the Andean deformational front. The lack of these coarse deposits in Lago Posadas suggests that the upper part of the SCF could have been removed by subsequent erosion. The lack of conglomeratic deposits in the upper reach of the SCF in Lago Posadas, such as those described for the Río Correntoso Formation (Ugarte, 1956; Escosteguy et al., 2003), can be explained by the removal of that part of the unit by subsequent erosion, evidenced by the flat modern terrace with a thin veneer of gravels that cover the unit in the area. This poses a question regarding the cause of this erosional episode, that appears to be absent in the northern region. One plausible explanation to this phenomenon could be the protection against erosion produced by modern plateau basalts. To the north, the equivalent Neogene succession shows a thick conglomerate succession which is directly covered by the Lago Buenos Aires Basalt (Escosteguy et al., 2003).

About $100 \mathrm{~km}$ to the northeast of Lago Posadas, some isolated outcrops of early Miocene terrestrial deposits were assigned to the Pinturas Formation (Bown and Larriestra, 1990). This unit is composed of a thin succession of pyroclastic rich deposits of aeolian origin, with mature paleosol development and several internal erosional unconformities (Bown and Larriestra, 1990). Some ages for this unit indicate partial synchronicity with the SCF in the Atlantic coast, varying roughly between 18 to $16 \mathrm{Ma}$ (Fleagle et al., 1995; Perkins et al., 2012). Other dates, plus biostratigraphic and sedimentological evidence, indicate a somewhat older age for the lower section of the Pinturas Formation (Bown and Fleagle, 1993; Kramarz and Bellosi, 2005; Perkins et al., 2012). The abundant pyroclastic material, the aeolian deposits and the mature paleosols all mark a strong difference with the SCF studied herein. Although partly contemporaneous, the connection between both sedimentary systems is no clear since the sedimentologic and stratigraphic differences are notorious. The Pinturas Formation is a thin package of sediments that rest directly on the Jurassic volcanic basement rocks, suggesting that this area was part of the Austral Basin margin, receiving sediments mostly from wind-derived explosive volcanism.

South of the study area, the SCF is extensively exposed along a narrow belt associated to the foothills of the Southern Patagonian Andes and farther south these exposures extends to the east reaching the Río Chalía (=Sehuén) and Río Santa Cruz, and the coastal area from Monte León to Río Gallegos. Most of the geological knowledge for the SCF comes from this southern area (e.g., Tauber, 1997a, b; Matheos and Raigemborn, 2012; Fernicola et al., 2014; Raigemborn et al., 2015; Cuitiño et al., 2016). In contrast, few studies describe the exposures along the western Andean foothills zone. In the southwestern margin of the Meseta Belgrano, 20 to $30 \mathrm{~km}$ south of Lago Posadas, the SCF is $650 \mathrm{~m}$-thick (Giacosa and Franchi, 2001). Farther south near Lago Argentino, Furque (1973) roughly described $500 \mathrm{~m}$ for the SCF. For the same area, Fernicola et al. (2014) described an isolated $100 \mathrm{~m}$-thick outcrop of tuff-rich deposits of the lower part of the SCF at Río Bote. Detailed 
stratigraphic and paleoenvironmental reconstructions for the SCF at these western exposures are lacking.

\subsection{Tectonic implications}

Several lines of evidence allow inferring that the deposition of the SCF is strongly linked with the evolution of the Southern Patagonian Andes. The most obvious link between Andean evolution and sedimentation is the outcrop and thickness distribution for this unit. The SCF of Lago Posadas (460 m-thick) is part of a narrow north-south belt that lies just east of the Andean foothills. As pointed above, the unit shows the greatest thickness close to the Andes, whereas it thins or pinches out to the east and southeast, where Tauber (1999) reports $220 \mathrm{~m}$ for the SCF in coastal localities.

In most of the exposures of the Austral Basin, the basal strata of the SCF (and its equivalents) are described as a transitional passage from the underlying marine or estuarine sediments (Feruglio, 1938). In particular, this passage is described in detail at Lago Argentino (Cuitiño and Scasso, 2010; Cuitiño et al., 2013), Monte León (Griffin and Parras, 2012; Cuitiño et al., 2016) and Lago Posadas (Cuitiño et al., 2015). This implies that the SCF is part of a high hierarchy sedimentation period that also involves the Patagonian marine sediments occurred during the early-mid Miocene. This early Miocene sedimentary package is regionally distributed in a large area of the Austral Basin, involving at least $90.000 \mathrm{~km}^{2}$ only in the Santa Cruz Province. Age constraints also suggest a close relationship between these early Miocene marine and continental deposits. The marine deposits were dated as Aquitanian-Burdigalian (23-18 Ma; Cuitiño et al., 2012; Parras et al., 2012; Cuitiño et al., 2015) whereas the terrestrial deposits were dated as Burdigalian-Langhian (18-14 Ma; Blisniuk et al., 2005; Perkins et al., 2012; Cuitiño et al., 2016). This means that no major breaks in sedimentation occurred during deposition of the early Miocene deposits in this portion of the Austral Basin.

The available uplift age constraints for the adjacent Southern Patagonian Andes indicate increased denudation rates starting at 30-23 Ma in the (western) basement domain and migrating eastward until $12 \mathrm{Ma}$ (Thomson, 2002). Other geochronometers reflect synchronous regional exhumation across the orogen between 22 and $18 \mathrm{Ma}$, while lower temperature chronometers give exhumation ages between 10 to $4 \mathrm{Ma}$ concentrated on the eastern fold and thrust belt (Thomson et al., 2010; Fosdick et al., 2013). The timing of uplift and erosion for the Southern Patagonian Andes coincides in part with the timing of deposition of the adjacent SCF. Considering that paleocurrent data for this unit suggest that the sediments arrived to the basin from the west (i.e., the Andes), it is reasonable to affirm that the SCF is a consequence of erosion in an actively rising orogen and subsequent deposition in the adjacent retroarc foreland basin.

Sandstone composition for the SCF in Lago Posadas indicates an immature tectonic setting for the origin of sediments (Fig. 8). Most of the particles are of volcanic composition typical of undissected volcanic arcs (Dickinson et al., 1983), suggesting the erosion of adjacent volcanic terrains. The scarcity of ash layers or juvenile volcanic particles such as glass shards or pumice particles, suggest little explosive volcanic activity during deposition of the SCF in this area. This is in marked contrast to the outcrops of the unit around Lago Argentino were primary pyroclastic material is abundant (Cuitiño and Scasso, 2013; Fernicola et al., 2014; Cuitiño et al., 2014), suggesting that for the time of deposition of the SCF, explosive volcanic activity was noticeably stronger at the southern part of the Austral Basin.

\subsection{Considerations on the fossil collection sizes and preservation}

The vertebrate fossil collection obtained from the SCF in the area of Lago Posadas is rather limited in relation to the prospecting effort, especially when compared with those localities of the southeast of Santa Cruz Province and Río Santa Cruz (see localities in Vizcaíno et al., 2012b and Fernicola et al., 2014). For instance, Bown and Fleagle (1993) reported that the joint expeditions by SUNY (USA) and Museo Argentino de Ciencias Naturales "Bernardino Rivadavia" (MACN, Argentina), between 1982 and 1992, collected more than 500 specimens of the tiny Santacrucian palaeothentid marsupials (and many others belonging to other taxa), much of them from the single locality Monte Observación (now Cañadón de las Vacas, see Vizcaíno et al., 2015, 2016c). Joint expeditions of the MLP (Argentina) and Duke University (DU, USA), starting in 2003, collected more than 1,600 specimens (many well- 
articulated) from the coastal localities between Río Coyle and Cabo Buen Tiempo (Vizcaíno et al., 2012a). Finally, recent collections by a tripartite team (MACN-MLP-DU) have collected probably more than 2000 specimens from the outcrops of the Río Santa Cruz that are currently under study (J.C. Fernicola, personal communication, 2017). The collection made by Hatcher housed at YPM includes about 954 specimens, mostly mammals, and some birds, while Brown's collection at AMNH includes about 94 specimens (Vizcaíno et al., 2013). Other old collections by H.T. Martin (1904) for the University of Kansas and E. Riggs for the Field Museum of Natural history of Chicago, collected between 235 and 395 specimens the former and 282 the latter, from the area between Río Gallegos and Río Coyle (Vizcaíno et al., 2013; Vizcaíno et al., 2016a).

Despite Hatcher's impression during his first visit to Lago Posadas in 1898 (Hatcher, 1903), other expeditions, including his own second try, were not much successful in terms of number of specimens collected. In February-March 1899, Hatcher returned to these outcrops with a second collector from PU and the novel paleontologist of the AMNH, B. Brown. According to Hatcher (1903) they spent two weeks in the area, where they gathered a "...considerable collection of vertebrates and invertebrates of the Santa Cruzian, Cape Fairweather and Patagonian beds". As already mentioned they must have collected between 50 and 60 specimens. Certainly, considering the number of personnel and days spent in the field, these amounts are much less than what can be collected from the SCF in other regions. As a guise of comparison with a contemporary collection, in 1887 Carlos Ameghino collected more than 2000 fossil pieces, comprising 120 new taxa (Rusconi, 1965; Fernicola, 2011a, b; Vizcaíno et al., 2013), from outcrops nearby the Río Santa Cruz and working alone for a month (Vizcaíno, 2011).

More recent expeditions did not gather larger collections either. In 1984, two members (Alfredo Carlini and Omar Molina) of the MLP expedition led by R. Pascual, collected about 20 specimens (Appendix 1), but observed some specimens in situ in the few hours they could spend in the outcrops (A. Carlini, personal communication, 2016); their exact location could not be established. In 2007 six members of the UNSJB-SUNY expedition spent two days in the area, and collected a few small mandibles
(L. González Ruiz, personal communication, 2017) and some scutes of the armadillos Proeutatus and Stenotatus (Dasypodidae), and the glyptodonts Eucinepeltus and Propalaehoplophorinae indet. (Glyptodontidae) (González Ruiz, 2012).

As the whole sample of Lago Posadas is small (barely reaching hundred specimens), some groups are under-represented in comparison with other Santacrucian outcrops, for example those of the Atlantic coastal and nearby localities (Vizcaíno et al., 2012b). In the east, metatherians are represented by 11 species of sparassodonts (Prevosti et al., 2012), four microbiotheres and about 10 species of paucituberculatans (Abello et al., 2012). In Lago Posadas, only the hathliacynid Cladosictis patagonica was recorded, and no paucituberculatans and microbiotheres were documented so far.

Within xenarthrans, in the east region cingulates are represented by at least five genera of armadillos and four genera of glyptodonts (Vizcaíno et al., 2012c), and pilosans by one genera of anteater and 11 genera of sloths (Bargo et al., 2012). In Lago Posadas only two genera of armadillos, some osteoderms of glyptodonts indet., and four genera of sloths were recorded. Among native ungulates, notoungulates are diverse and abundant in eastern Santacrucian outcrops, including three genera of Toxodontia (two toxodontids and one homalodotheriid), and four genera of Typotheria (two interatheriids and two hegetotheriids) (Cassini et al., 2012). The record in Lago Posadas is good in terms of taxa: two genera of Toxodontia and four of Typotheria. The same is true for litopterns, represented by five genera in the coastal and nearby localities, four of them recorded at Lago Posadas. Astrapotheres include one genera and one species, and one specimen catalogued as Astrapotheriidae indet. Last, rodents are very frequent and diverse in the eastern localities, being represented by about 14 genera of the main four groups of caviomorphs (Cavioidea, Chinchilloidea, Octodontoidea and Erethizontoidea; Candela et al., 2012). At Lago Posadas only four genera of cavioids were recorded.

The preservation of the new remains collected by our team since 2010 is rather poor. We found only two specimens in situ, which consist of fragmentary skulls and mandibles of large notoungulates (Appendix 1). The fossils collected by the 1984 MLP and 2007 UNSJB-SUNY expeditions are also fragmentary, but according to A. Carlini, personal communication, 
2017, the specimens in situ observed were in good conditions. This is in accordance with the fact that in the collection at YPM there are several wellpreserved specimens, including an almost complete bird skeleton and skulls of different sizes, most of them extracted from concretions (Fig. 10).

The possibility exists that certain facies in restricted areas provided the concretions that contained the best-preserved specimens collected and those observed by the 1984 MLP crew, but we have been unable to find those particular spots yet. Based on the few in situ specimens collected by us, plus the observation of the sediment matrix from specimens housed in collections, it seems that many vertebrate fossils are preserved in sheet sandstone levels of FA 2 (floodplain deposits). These sandstones represent episodes of fast sedimentation rates in the floodplain produced during flood stages or during channel avulsions, which promoted quick burying of carcasses. Beyond that, it seems clear that the Lago Posadas area is not as fossiliferous as other extra-Andean outcrops of the SCF. Furthermore, the tiniest mammals, which are highly frequent in other localities, are lacking in all the collections made so far. For instance, as mentioned above, in taxonomic terms it implies the complete absence of pauciturbeculatan and microbiotherian marsupials, otherwise frequent in other places (Bown and Fleagle, 1993; Abello et al., 2012).

The cause of the poor fossil content relative to other exposures of the SCF of the Austral Basin is not clear, although different explanations can be considered. Paleoenvironments of deposition interpreted from SCF exposures from Lago Posadas and southern Santa Cruz region are similar. Matheos and Raigemborn (2012) and Raigemborn et al. $(2015,2018)$ highlight that the SCF in SE Santa Cruz Province was produced by a fluvial system with channels of low energy and low sinuosity, enclosed in a broad floodplain, conclusions that are analogous to those arrived in this work. Also, sedimentation rates for the SCF calculated for both regions are nearly similar (Perkins et al., 2012; Cuitiño et al., 2016) suggesting that this variable cannot be used as the cause of the difference in overall fossil abundance. In contrast, two main differences between them can be recognized. One is sediment composition, with very high proportion of pyroclastic material recognized for the SCF in the southeastern regions, whereas very few pyroclastic sediments are described for the SCF in Lago Posadas (see section 5.2). The recurrent supply of fine-grained pyroclastic material in the southeastern region that repeatedly mantled the paleosurfaces (Perkins et al., 2012; Matheos and Raigemborn, 2012; Raigemborn et al., 2015), could be the cause of the relatively higher preservation potential through fast burial of death animals, such as was previously proposed (e.g., Hunt, 1990). The second cause of differential fossil preservation is related to present-day rock stability. Rocks of the SCF in Lago Posadas are more resistant to erosion than in other outcrops further south and east, so the "release rate" of fossils could be comparatively much lower.

\subsection{Biostratigraphic implications}

The reduced number of specimens collected in the field effort performed in the last decades, and the absence of key taxa among them, makes only possible to assign the fossil collection to a Santacrucian Age sensu lato. Furthermore, as most specimens were found loose and, in some cases, the exact provenance of this material is not confidently established, their biostratigraphic value remains limited.

The study of the older collections at YPM allows postulating some interesting working hypothesis. In a series of exhaustive monographs in the Reports of the Princeton University Expeditions to Patagonia, edited by W. Scott between 1903 and 1932, several new fossil taxa were described based on material from Lago Pueyrredón. Up to date, these taxa have not been cited for other SCF localities. Among them, it is the phorusrhacid bird Pelecyornis pueyrredonensis Sinclair and Farr, which is now considered a synonym of Psilopterus bachmanni (Moreno and Mercerat) (Alvarenga and Höfling, 2003), a taxon present in other Santacrucian localities (Degrange et al., 2012 and references therein). According to Pérez (2010), Schistomys rollinsii Scott is a valid species of "ecoardid" rodent. However, because this species can only be distinguished from others of the same genus from cranial features, it cannot be ruled out its presence in other localities where the genus is represented only by teeth (M.E. Pérez, personal communication, 2016). Following González Ruiz (2010), Metopotoxus anceps Scott, corresponds to a different taxon from other Propalaehoplophorinae glyptodonts, although its inclusion within that genus is questionable. The sloth Hapalops vulpiceps Scott, 
and the toxodontid Nesodon cornutus Scott, have not been recorded in other areas besides Lago Posadas. The taxonomic validity of both taxa has not been formally questioned, but preliminary observations suggest that their morphology falls within the range of variability of other species of those genera (see Hernández del Pino, 2018 for Nesodon spp). Taxonomic revisions of all these taxa are necessary to adjust their biostratigraphic significance.

If Schistomys rollinsii, Metopotoxus anceps, Hapalops vulpiceps and Nesodon cornutus were confirmed as valid species which are absent in other localities of the SCF, this may be interpreted as reflecting either temporal, geographic or ecological differences, as it was also proposed for other Santacrucian faunas (Fernicola et al., 2014; Cuitiño et al., 2016). Certainly, if they were absent in synchronous levels of other localities, differences would imply ecological or geographical, rather than temporal, factors. A larger sample with more precise chronologic/stratigraphic control is also needed.

\subsection{Paleoecology}

As it was discussed above, the facies analysis for the SCF in Lago Posadas indicates that the unit was deposited in a low-gradient fluvial system with extensive floodplains traversed by sand-dominated fluvial channels. The abundance of dark reddish floodplain deposits and the lack of vegetal fossil remains, suggest oxygenated environments with low proportion of preserved organic matter. Some calcareous nodules, cutans and root traces suggest paleosol formation (Retallack, 2001), most of which show evidences of poor maturity. The lack of welldeveloped paleosol horizons suggests continuous, relatively high sedimentation rates. The presence of some paleosol horizons, in some occasion with carbonate nodules (calcretes), suggests the occurrence of short periods of floodplain stability and a semi-arid environment. This is especially evident for the lower third of the SCF, while for the upper two thirds the scarcity of paleosol horizons suggests environmental changes, probably linked to augmented sedimentation rates and/or climate deterioration. Similar sedimentary paleoenvironments are proposed for the SCF in the southeast of Santa Cruz (Tauber, 1994; Matheos and Raigemborn, 2012; Raigemborn et al., 2015, 2018), from which most of the paleoecological data for the SCF is derived.
In these later examples, a marked seasonality was proposed (Kay et al., 2012; Raigemborn et al., 2015, 2018).

The integrated list of taxa recorded by the PU and MLP expeditions, and by us do not allow performing an exhaustive paleoecological analysis such as that of Kay et al. (2012) for the exposures of the SCF in the Atlantic coast. The sample considered is not only small, but it may also be time-averaged, allowing only broad considerations about the paleoecology of the Lago Posadas fauna.

The record of arboreal, browser and frugivore mammals indicates the presence of trees. The occurrence of grazer mammals and rheas suggests also the existence of open environments. With the available evidence, it cannot be asserted if these two environments coexisted or alternated during all the time of deposition of the formation. However, it is clear that they did coexist in the Eastern areas, under mean annual temperature of about $20^{\circ} \mathrm{C}$ and about $1,500 \mathrm{~mm}$ of mean annual precipitation, with a marked seasonality in day length (Kay et al., 2012)

Among primary consumers, most of the categories analyzed for the East are present in the mammal assemblage of Lago Posadas. Within them, the frugivores are underrepresented and there are not specialized seed feeders, although this could be an artifact. Albeit larger, the number of frugivore taxa in the East is also low, and the majority falls within the smaller body mass categories for mammals (I and II). Kay et al. (2012) speculated about the low number of frugivores, suggesting that could be a consequence of the extreme seasonality of fruit production at these latitudes or that the fruits may have been present but the frugivores were birds, which have much lower preservation potential than mammals.

Conversely, the secondary consumers are clearly underrepresented at Lago Posadas when comparing with other Santacrucian faunas. For instance, among mammals, only one sparassodont (hathliacynid) was recorded, a semiarboreal predator of body mass category III (less than 10 kilograms). In the coastal localities, the predator niche includes three genera of hathliacynids and five genera of borhyaenoids, comprising both semiarboreal and ground dwelling forms within the body mass categories II-IV (up to 50 kilograms). As secondary consumers are always much less abundant than primary consumers, this difference could be due to the comparatively small sample size of Lago Posadas. 
Only one scavenger/insectivorous armadillo is recorded in Lago posadas, while scavengers are represented by two or three genera of armadillos in the coastal localities. Specialized insectivores are not recorded in Lago Posadas. In the coastal localities they are represented by a diversity of palaeothentiid and microbiotheriid metatheres and the enigmatic Necrolestes (all of less than one kilogram), and the proposed strict anteater Protamandua (four kilograms). Among birds, only one genera of small phorusrhacid appears at Lago Posadas, while in the coastal and nearby localities four genera of phorusrhacids and a seriema occupied the predator niche along with metatheres.

\section{Conclusions}

Sedimentologic field survey of the SFC in Lago Posadas revealed that the unit is composed of $460 \mathrm{~m}$ of a mud-dominated succession with sandstone intercalations, interpreted as deposited in a low-gradient fluvial system. The lowermost interval of the unit represents the transition from restricted marine deposits, which grade upward to fluvial deposits without any recognizable break in sedimentation. Floodplain deposits dominate the succession being composed of mudstones and thin sheet to wedge sandstones, the later deposited by crevasse splay episodes. In turn, relatively thick sandstone lenses indicate deposition within fluvial channels. Conglomerates are nearly absent in the succession. The dominance of crevasse splay deposits and the lack of evidence for channel lateral migration suggest deposition in an anastomosed fluvial setting. The ratio of floodplain/channel deposits allows classifying these deposits as a high accommodation fluvial system, associated to active subsidence during the time of deposition.

Reddish floodplain deposits dominate the lower third of the SCF, including horizons of poorly developed paleosols under well-drained, oxidizing conditions. The lack of well-developed paleosol horizons suggests continuous, relatively high sedimentation rates. The presence of some paleosol horizons, in some occasion with carbonate nodules (calcretes), suggests short periods of floodplain stability and a semi-arid temperate environment. This is especially evident for the lower third of the SCF, while for the upper two thirds the scarcity of paleosol horizons suggests environmental changes, probably linked to increased sedimentation rates and/or climate deterioration. Paleocurrent data from cross-bedded channeled sandstones indicate a strong unidirectional pattern for sediment dispersal from west to east, i.e., from the Southern Patagonian Andes to the foreland region. In turn, sandstone composition indicates dominance of lithic volcanic particles, which are thought to be originated after erosion of the basin basement assigned to the Jurassic El Quemado Complex, located to the west.

A slight coarsening upward trend is recognized for the SCF, as well as a subtle upward increase in sandstone proportion, suggesting progressive reduction in accommodation.

The exposures of the SCF in Lago Posadas are significantly less fossiliferous in terms of vertebrates than other classical localities in the south, such as those from the Atlantic coast and the Río Santa Cruz. Consequently, the list of fossils may under represent the real taxonomic richness of the locality. In addition, the vertebrate fossil sample is size-biased, with a noticeable under representation of the smaller taxa well recorded in other outcrops of the SCF. The cause of the reduced fossil vertebrates abundance may be explained by different sediment composition or different "release rate" of fossils.

The fossil vertebrates collected so far allows a Santacrucian Age sensu lato assignment for the fauna of the SFC at Lago Posadas. Taxonomic revisions of several taxa are needed in order to adjust their biostratigraphic significance. The specimens recently collected, summed to those in museum collections, show some differences with the typical Santacrucian association. These faunal differences in relation to other synchronous localities may reflect ecological or geographical, rather than temporal, controlling factors. The combined record of arboreal, browser and frugivores on one side, and grazer mammals and rheas on the other, suggest the presence of both trees and open environments for the SCF in Lago Posadas. Frugivores, among primary consumers, and the secondary consumers guild are under-represented due to sample and fossil remain size biases.

For sub-Andean localities of the SCF, the uplifting orogen acted as a primary control on basin subsidence, sediment supply and climate, thus providing a special signature on the sedimentary and paleontological record. 


\section{Acknowledgments}

We especially thank the owners and workers of Estancia El Chacay for their logistic support during fieldwork in the area, and people who helped during fieldwork: J.C. Fernicola (MACN-CONICET), L. Cataldi (UBA), G. Ronda (IDEAN-UBA) and P. Alonso Muruaga (IGEBA-UBA). We also thank the collection and archives managers D. Brinkman (YPM), J. Gaulkin and S. Bell (AMNH), M. Reguero y A. Scarano (MLP) for access to the specimens and information, and several colleagues for the identification of specimens: $F$. Degrange, J.C. Fernicola, A. Racco, N. Muñoz, M. Fernández, M. Arnal, M.E. Pérez, A. Forasieppi, F. Prevosti, S. Hernández del Pino. We are grateful to the reviewers R. Ugalde and E. Bellosi for their comments and suggestions, which allowed improving this manuscript. This work was funded by Agencia Nacional de Promoción Científica y Tecnológica through the grants PICT 2013-398 (JIC), PICT 2013-389 (SFV) and PICT 2017-1081 (MSB), a postgraduate grant from the International Association of Sedimentologists (JC), and National Science Foundation grants EAR0851272 and EAR1348259, and CP-030R-17 (R.F. Kay and SFV).

\section{References}

Abello, M.A.; Ortiz-Jaureguizar.E.; Candela, A.M. 2012. Paleoecology of the Paucituberculata and Microbiotheria (Mammalia, Marsupialia) from the late Early Miocene of Patagonia. In Early Miocene Paleobiology in Patagonia: high-latitude paleocommunities of the Santa Cruz Formation (Vizcaíno, S.F.; Kay, R.F.; Bargo, M.S.; editors). Cambridge University Press: 156-172. Cambridge.

Alonso-Zarza, A.M. 2003. Palaeoenvironmental significance of palustrine carbonates and calcretes in the geological record. Earth Science Reviews 60: 261-298.

Alvarenga, H.M.F.; Höfling, E. 2003. Systematic revision of the Phorusrhacidae (Aves: Ralliformes). Papéis Avulsos de Zoologia 43 (4): 55-91. São Paulo.

Ameghino, F. 1906. Les formations sédimentaires du Crétacé Superieur et du Tertaire de Patagonie avec un parallele entre leurs faunes mammalogiques et celles de l'ancien continent. Anales del Museo Nacional de Buenos Aires 15: 1-568.

Bande, A.E. 2007. Geología y sedimentología del Cenozoico de la margen sur del Lago Posadas, provincia de Santa Cruz. Trabajo Final de Licenciatura (Inédito), Universidad de Buenos Aires: 97 p.

Bargo, M.S.; Toledo, N.; Vizcaíno, S.F. 2012. Paleobiology of the Santacrucian sloths and anteaters (Xenarthra, Pilosa). In Early Miocene Paleobiology in Patagonia: high-latitude paleocommunities of the Santa Cruz Formation (Vizcaíno, S.F.; Kay, R.F.; Bargo, M.S.; editors). Cambridge University Press: 216-242. Cambridge.

Bellosi, E.S. 1995. Paleogeografía y cambios ambientales de la Patagonia central durante el Terciario medio. Boletín de Informaciones Petroleras 44 (5): 50-83.

Blisniuk, P.M.; Stern, L.A.; Chamberlain, C.P.; Idleman, B.; Zeitler, P.K. 2005. Climatic and ecologic changes during Miocene surface uplift in the Southern Patagonian Andes. Earth and Planetary Science Letters 230: 125-142.

Bostelmann, J.E.; Buldrini, K.E. 2012. Late-early Miocene fossil mammals of the Pampa Guadal area, Meseta Cosmelli, Aysén Region, Chilean Patagonia. In Simposio de Paleontología de Chile, No. 3, Abstract Book: 38-41.

Bostelmann, J.E.; Le Roux, J.P.; Vásquez, A.; Gutiérrez, N.M.; Oyarzún, J.L.; Carreño, C.; Torres, T.; Otero, R.; Llanos, A.; Fanning, C.M.; Hervé, F. 2013. Burdigalian deposits of the Santa Cruz Formation in the Sierra Baguales, Austral (Magallanes) Basin: age, depositional environment and vertebrate fossils. Andean Geology 40 (3): 458-489. doi: 10.5027/ andgeoV40n3-a04.

Bown, T.M.; Larriestra, C.N. 1990. Sedimentary paleoenvironments of fossil platyrrhine localities, Miocene Pinturas Formation, Santa Cruz Province, Argentina. Journal of Human Evolution 19: 87-119.

Bown, T.M.; Fleagle, J.G. 1993. Systematics, biostratigraphy, and dental evolution of the Palaeothentidae, later Oligoceneto Early-Middle Miocene (DeseadanSantacrucian) Caenolestoid Marsupials of South America. Journal of Palaeontology, Memoir 67 (29): 1-76.

Burns, C.E.; Mountney, N.P.; Hodgson, D.M.; Colombera, L. 2017. Anatomy and dimensions of fluvial crevassesplay deposits: Examples from the Cretaceous Castlegate Sandstone and Neslen Formation, Utah, USA. Sedimentary Geology 351: 21-35.

Candela, A.M.; Rasia, L.L.; Pérez, M.E. 2012. Paleobiology of Santacrucian caviomorph rodents: a morphofunctional approach. In Early Miocene Paleobiology in Patagonia: high-latitude paleocommunities of the Santa Cruz Formation (Vizcaíno, S.F.; Kay, R.F.; Bargo, M.S.; editors). Cambridge University Press: 287-305. Cambridge.

Carlini, A.A.; Scillato-Yané, G.J.; Vizcaíno, S.F. 1993. Un myrmecophagidae (Vermilingua) del Mioceno de Cerro Boleadoras (Santa Cruz, Argentina). Ameghininana 30 (1): 102. 
Cassini, G.H.; Cerdeño, E.; Villafañe, A.L.; Muñoz, N.A. 2012. Paleobiology of native ungulates (Meridiungulata: Astrapotheria, Litopterna and Notoungulata). In Early Miocene Paleobiology in Patagonia: high-latitude paleocommunities of the Santa Cruz Formation (Vizcaíno, S.F.; Kay, R.F.; Bargo, M.S.; editors). Cambridge University Press: 243-286. Cambridge.

Catuneanu, O. 2006. Principles of Sequence Stratigraphy. Elsevier: 375 p. Amsterdam.

Chiesa, J.O.; Camacho, H.H. 1995. Litoestratigrafía del Paleógeno marino en el noroeste de la provincia de Santa Cruz, Argentina. Monografías de la Academia Nacional de Ciencias Exactas, Físicas y Naturales de Buenos Aires 11, Parte I: 9-15.

Cuitiño, J.I.; Scasso, R.A. 2010. Sedimentología y paleoambientes del Patagoniano y su transición a la Formación Santa Cruz al sur del Lago Argentino, Patagonia Austral. Revista de la Asociación Geológica Argentina 66 (3): 406-417.

Cuitiño, J.I.; Scasso, R.A. 2013. Reworked pyroclastic beds in the early Miocene of Patagonia: Reaction in response to high sediment supply during explosive volcanic events. Sedimentary Geology 289: 194-209.

Cuitiño, J.I.; Pimentel, M.M.; Ventura Santos, R.; Scasso, R.A. 2012. High resolution isotopic ages for the "Patagoniense" transgression in southwest Patagonia: stratigraphic implications. Journal of South American Earth Sciences 38: 110-122.

Cuitiño, J.I.; Ventura Santos, R.; Scasso, R.A. 2013. Insights into the distribution of shallow marine/estuarine early Miocene oysters from Southwestern Patagonia: sedimentologic and stable isotope constraints. Palaios 28: 583-598.

Cuitiño, J.I.; Fernicola, J.C.; Vizcaíno, S.F.; Bargo, M.S.; Kay, R.F. 2014. Variaciones proximales-distales (O-E) en la Formación Santa Cruz, Mioceno de la Cuenca Austral. In Reunión Argentina de Sedimentología, No. 14, Abstracts Book: 89-90. Puerto Madryn.

Cuitiño, J.I.; Ventura Santos, R.; Alonso Muruaga, P.J.; Scasso, R.A. 2015. Sr-stratigraphy and sedimentary evolution of early Miocene marine foreland deposits in the northern Austral (Magallanes) Basin, Argentina. Andean Geology 42 (3): 364-385. doi: 10.5027/ andgeoV42n3-a05.

Cuitiño, J.I.; Fernicola, J.C.; Kohn, M.; Kay, R.F.; Trayler, R.; Naipauer, M.; Bargo, M.S.; Vizcaíno, S.F. 2016. $\mathrm{U}-\mathrm{Pb}$ geochronology of the Santa Cruz Formation (early Miocene) at the Río Bote and Río Santa Cruz (southernmost Patagonia, Argentina): implications for the correlation of fossil vertebrate localities. Journal of South American Earth Sciences 70: 198-210.
Dal Molin, C.N.; Colombo, F. 2003. Sedimentación neógena en la Cuenca del Río Zeballos y del Río Jenimeni ( $47^{\circ}$ de Latitud Sur). Antepaís Patagónico, Argentina. Geogaceta 34: 139-142.

De Barrio, R.E.: Scillato-Yané, G.; Bond, M. 1984. La Formación Santa Cruz en el borde occidental del Macizo del Deseado (Provincia de Santa Cruz) y su contenido paleontológico. In Congreso Geológico Argentino, No. 9, Actas IV: 539-556. San Carlos de Bariloche

Degrange, F.J.; Noriega, J.I.; Areta, J.I. 2012. Diversity and paleobiology of the Santacrucian birds. In Early Miocene Paleobiology in Patagonia: high-latitude paleocommunities of the Santa Cruz Formation (Vizcaíno, S.F.; Kay, R.F.; Bargo, M.S.; editors). Cambridge University Press: 138-155. Cambridge.

De la Cruz, R.; Suárez, M. 2006. Geología del área Puerto Guadal-Puerto Sánchez, Región Aisén del General Carlos Ibáñez del Campo. Servicio Nacional de Geología y Minería, Carta Geológica de Chile, Serie Geológica Básica 95: 58 p., 1 mapa escala 1:100.000. Santiago.

Dickinson, W.R.; Beard, L.S.; Brakenridge, G.R.; Ejavec, J.L.; Ferguson, R.C.; Inman, K.F.; Knepp, R.A.; Lindberg, F.A.; Ryberg, P.T. 1983. Provenance of North American Phanerozoic sandstones in relation to tectonic setting. Geological Society of America Bulletin 94: 222-235.

Eren, M.; Kadir, S.; Kapur, S.; Huggett, J.; Zucca, C. 2015. Colour origin of Tortonian red mudstones within the Mersin area, southern Turkey. Sedimentary Geology 318: 10-19.

Escosteguy, L.; Dal Molin, C.; Franchi, M.; Geuna, S.; Lapido, O. 2003. Hoja Geológica 4772-II Lago Buenos Aires. Programa Nacional de Cartas Geológicas de la República Argentina 1:250.000. Servicio Geológico Minero, Boletín 339: 80 p.

Fernicola, J.C. 2011a. Implicancias del conflicto AmeghinoMoreno sobre la colección de mamíferos fósiles realizada por Carlos Ameghino en su primera exploración al río Santa Cruz, Argentina. Revista Museo Argentino de Ciencias Naturales 13 (1): 41-57.

Fernicola, J.C. 2011b. 1886-1888: Ascenso, auge y caída de la sociedad entre Florentino Ameghino y Francisco P. Moreno. In Vida y obra de Florentino Ameghino (Fernicola, J.C.; Prieto, A.; Lazo, D.; editors). Asociación Paleontológica Argentina, Publicación Especial 12: 35-49. Buenos Aires.

Fernicola, J.C.; Cuitiño, J.I.; Vizcaíno, S.F.; Bargo, M.S.; Kay, R.F. 2014. Fossil localities of the Santa Cruz formation (early Miocene, Patagonia, Argentina) prospected by Carlos Ameghino in 1887 revisited and 
the location of the Notohippidian. Journal of South American Earth Sciences 52: 94-107.

Feruglio, E. 1938. Relaciones estratigráficas entre el Patagoniano y el Santacruciano en la Patagonia Austral. Revista del Museo de La Plata, Geología 4: 129-159.

Feruglio, E. 1949. Descripción Geológica de la Patagonia. Dirección General de Yacimientos Petrolíferos Fiscales, 3 Tomos, T1: 1-323; T2: 1-349; T3: 1-331. Buenos Aires.

Fleagle, J.G.; Bown, T.M.; Swisher III, C.C.; Buckley, G.A. 1995. Age of the Pinturas and Santa Cruz Formations. In Congreso Argentino de Paleontología y Bioestratigrafía, No. 6, Actas: 129-135. Trelew.

Flint, S.S.; Prior, D.J.; Agar, S.M.; Turner, P. 1994. Stratigraphic and structural evolution of the Tertiary Cosmelli Basin and its relationship to the Chile triple junction. Journal of the Geological Society 151: 251-268.

Flynn, J.J.; Novacek, M.J.; Dodson, H.E.; Frassinetti, D.; McKenna, M.C.; Norell, M.A.; Sears, K.E.; Swisher, C.C.; Wyss, A.R. 2002. Anew fossil mammal assemblage from the southern Chilean Andes: implications for geology, geochronology, and tectonics. Journal of South American Earth Sciences 15: 285-302.

Folk, R.L.; Andrews, P.B.; Lewis, D.W. 1970. Detrital sedimentary rock classification and nomenclature for use in New Zealand. New Zealand Journal of Geology and Geophysics 13: 937-968.

Fosdick, J.C.; Grove, M.; Hourigan, J.K.; Calderón, M. 2013. Retroarc deformation and exhumation near the end of the Andes, southern Patagonia. Earth and Planetary Science Letters 361: 504-517.

Furque, G. 1973. Descripción geológica de la Hoja 58b, Lago Argentino, provincia de Santa Cruz. Servicio Nacional Minero Geológico, Boletín 140: 1-49.

Ghiglione, M.C.; Naipauer, M.; Sue, Ch.; Barberón, V.; Valencia, V.; Aguirre-Urreta, B.; Ramos, V.A. 2015. $\mathrm{U}-\mathrm{Pb}$ zircon ages from the northern Austral basin and their correlation with the Early Cretaceous exhumation and volcanism of Patagonia. Cretaceous Research 55: 116-128.

Ghiglione, M.C.; Ramos, V.A.; Cuitiño, J.; Varberón, V. 2016a. Growth of the Southern Patagonian Andes $\left(46-53^{\circ} \mathrm{S}\right)$ and their Relation to Subduction Processes. In Growth of the Southern Andes (Folguera, A.; Naipauer, M.; Sagripanti, L.; Ghiglione, M.C.; Orts, D.L.; Giambiagi, L.; editors). Springer Earth Systems Sciences: 201-240.

Ghiglione, M.C.; Sue, Ch.; Ramos M.E.; Tobal, J.E.; Gallardo, R.E. 2016b. The relation between Neogene denudation of the Southernmost Andes and sedimentation in the offshore Argentine and Malvinas Basins during the opening of the Drake Passage. In Geodynamic Evolution of the Southernmost Andes (Ghiglione, M.C.; editor). Springer Earth Systems Sciences: 109-135.

Giacosa, R.; Franchi, M. 2001. Hojas Geológicas 4772-III y 4772-IV Lago Belgrano y Lago Posadas, Provincia de Santa Cruz. Programa Nacional de Cartas Geológicas de la República Argentina. Servicio Geológico Minero Argentino, Instituto de Geología y Recursos Minerales, Boletín 256.

Gibling, M.R. 2006. With and thickness of fluvial channel bodies and valley fills in the geological record: a literature compilation and classification. Journal of Sedimentary Research 76: 731-770.

González Ruiz, L. 2010. Los Cingulata (Mammalia, Xenarthra) del Mioceno temprano y medio de Patagonia (edades Santacrucense y "Friasense"). Revisión sistemática y consideraciones bioestratigráficas. Ph.D. Thesis (Unpublished), Universidad Nacional de La Plata: 486 p.

González Ruiz, L. 2012. Los Cingulata (Mammalia, Xenarthra) del Santacrucense sensu lato de Lago Posadas (Argentina). Ameghiniana 49 (4): R28.

Gorring, M.L.; Kay, S.M.; Zeitler, P.K.; Ramos, V.A.; Rubiolo, D.; Fernández, M.I.; Panza, J.L. 1997. Neogene Patagonian plateau lavas: continental magmas associated with ridge collision at the Chile Triple Junction. Tectonics 16: 1-17.

Griffin, M.; Parras, A. 2012. Oysters from the base of the Santa Cruz Formation (late Early Miocene) of Patagonia. In Early Miocene Paleobiology in Patagonia: high-latitude paleocommunities of the Santa Cruz Formation (Vizcaíno, S.F.; Kay, R.F.; Bargo, M.S.; editors). Cambridge University Press: 83-90. Cambridge.

Hatcher, J.B. 1900. Sedimentary rocks of southern Patagonia. American Journal of Science (1880-1910), Serie 4 (9): 85-108.

Hatcher, J.B. 1903. Narrative of the expedition. In Reports of the Princeton University Expeditions to Patagonia, 1896-1899. Vol. 1, Narrative and geography (Scott, W.B.; editor). Princeton University Press: 296 p.

Hernández del Pino, S.E. 2018. Anatomía y Sistemática de los Toxodontidae (Notoungulata) de la Formación Santa Cruz, Mioceno Temprano, Argentina. Ph.D. Thesis (Unpublished), Universidad Nacional de La Plata: 1-415.

Hunt, R.M.Jr. 1990. Taphonomy and sedimentology of Arikaree (lower Miocene) fluvial, eolian, and 
lacustrine paleoenvironments, Nebraska and Wyoming; A paleobiota entombed in fine-grained volcaniclastic rocks. In Volcanism and fossil biotas: Boulder, Colorado (Lockley, M.G.; Rice, A.; editors). Geological Society of America, Special Paper 244: 69-111.

Kay, R.F.; Vizcaíno, S.F.; Bargo, M.S. 2012. A review of the paleoenvironment and paleoecology of the Miocene Santa Cruz Formation. In Early Miocene Paleobiology in Patagonia: high-latitude paleocommunities of the Santa Cruz Formation (Vizcaíno, S.F.; Kay, R.F.; Bargo, M.S.; editors). Cambridge University Press: 331-365. Cambridge.

Kramarz, A.G.; Bellosi, E.S. 2005. Hystricognath rodents from the Pinturas Formation, Early-Middle Miocene of Patagonia, biostratigraphic and paleoenvironmental implications. Journal of South American Earth Sciences 18: 199-212.

Krauss, M.J. 1999. Paleosols in clastic sedimentary rocks: their geologic applications. Earth-Science Reviews 47: 41-70.

Makaske, B. 2001. Anastomosing rivers: a review of their classification, origin and sedimentary products. EarthScience Reviews 53: 149-196.

Makaske, B.; Lavooi, E.; Haas, T.; Kleinhans, M.G.; Smith, D.G. 2017. Upstream control of river anastomosis by sediment overloading, upper Columbia River, British Columbia, Canada. Sedimentology 64: 1488-1510.

Malumián, N.; Náñez, C. 2011. The Late Cretaceous-Cenozoic transgressions in Patagonia and the Fuegian Andes: foraminifera, palaeoecology, and palaeogeography. Biological Journal of the Linnean Society 103: 269-288.

Marshall, L.G.; Hoffstetter, R.; Pascual, R. 1983. Mammals and stratigraphy: geochronology of the continental mammal-bearing Tertiary of South America. Paleovertebrata, Mémoire Extraordinaire: 1-93.

Martin, H.T. 1904. A collecting trip to Patagonia, South America. Transactions of the Kansas Academy of Science 19: 101-104.

Matheos, S.D.; Raigemborm, M.S. 2012. Sedimentology and paleoenvironment of the Santa Cruz Formation. In Early Miocene Paleobiology in Patagonia: highlatitude paleocommunities of the Santa Cruz Formation (Vizcaíno, S.F.; Kay, R.F.; Bargo, M.S.; editors). Cambridge University Press: 59-82. Cambridge.

Miall, A.D. 1985. Architectural-Element Analysis: A New Method of Facies Analysis Applied to Fluvial Deposits. Earth-Science Reviews 22: 261-308.

Miall, A.D. 1996. The geology of fluvial deposits. Sedimentary facies, basin analysis, and petroleum geology. Springer-Verlag: 582 p. Berlin.
Muñoz, N.A. 2017. Esqueleto apendicular de tipoterios (Notoungulata) y caviomorfos (Rodentia) de la Formación Santa Cruz (Mioceno Inferior alto). Implicancias paleoecológicas. Ph.D. Thesis (Unpublished), Universidad Nacional de La Plata: 290 p.

Niemeyer, H.; Skármeta, J.; Fuenzalida, R.; Espinosa, W. 1984. Hojas Peninsula de Taitao y Puerto Aysén. Servicio Nacional de Geología y Minería, Carta Geológica de Chile, Serie Geología Básica 60-61: 80 p.

Palazzesi, L.; Barreda, V.D.; Cuitiño, J.I.; Guler, M.V.; Tellería, M.C.; Ventura Santos, R. 2014. Fossil pollen records indicate that Patagonian desertification was not solely a consequence of Andean uplift. Nature Communications 5 (3558). doi: 10.1038/ncomms4558.

Parras, A.; Dix, G.R.; Griffin, M. 2012. Sr-isotope chronostratigraphy of Paleogene-Neogene marine deposits: austral Basin, southern Patagonia (Argentina). Journal of South American Earth Sciences 37: 122-135.

Pascual, R.; Ortega Hinojosa, E.J.; Gondar, D.; Tonni, E.P. 1965. Las Edades del Cenozoico mamalífero de la Argentina, con especial atención a aquellas del territorio bonaerense. Anales de la Comisión de Investigaciones Científicas de la Provincia de Buenos Aires 6: 165-193.

Pérez, M.E. 2010. Sistemática, ecología y bioestratigrafía de Eocardiidae (Rodentia, Hystricognathi, Cavioidea) del Mioceno temprano y medio de Patagonia. Ph.D. Thesis (Unpublished), Universidad Nacional de La Plata: $385 \mathrm{p}$.

Perkins, M.E.; Fleagle, J.G.; Heizler, M.T.; Nash, B.; Bown, T.M.; Tauber, A.A.; Dozo, M.T. 2012. Tephrochronology of the Miocene Santa Cruz and Pinturas Formations, Argentina. In Early Miocene Paleobiology in Patagonia: high-latitude paleocommunities of the Santa Cruz Formation (Vizcaíno, S.F.; Kay, R.F.; Bargo, M.S.; editors). Cambridge University Press: 23-40. Cambridge.

Prevosti, F.J.; Forasiepi, A.M.; Ercoli, M.D.; Turazzini, G.F. 2012. Paleoecology of the mammalian carnivores (Metatheria, Sparassodonta) of the Santa Cruz Formation (late Early Miocene). In Early Miocene Paleobiology in Patagonia: high-latitude paleocommunities of the Santa Cruz Formation (Vizcaíno, S.F.; Kay, R.F.; Bargo, M.S.; editors). Cambridge University Press: 173-193. Cambridge.

Raigemborn, M.S.; Matheos, S.D.; Krapovickas, V.; Vizcaíno, S.F.; Bargo, M.S.; Kay, R.F.; Fernicola, J.C.; Zapata, L. 2015. Paleoenvironmental reconstruction of the coastal Monte León and Santa Cruz formations (Early Miocene) at Rincón del Buque, Southern 
Patagonia: A revisited locality. Journal of South American Earth Sciences 60: 31-55.

Raigemborn, M.S.; Krapovickas, V.; Beilinson, E.; Peral, L.E.G.; Zucol, A.F.; Zapata, L.; Kay, R.F.; Bargo, M.S.; Vizcaíno, S.F.; Sial, A.N. 2018. Multiproxy studies of Early Miocene pedogenic calcretes in the Santa Cruz formation of southern Patagonia, Argentina indicate the existence of a warm temperate vegetation adapted to a fluctuating water table. Palaeogeography, Palaeoclimatology, Palaeoecology 500: 1-23.

Ramos, V.A. 1989. Andean foothills structures in northern Magallanes Basin, Argentina. American Association of Petroleum Geologists 73: 887-903.

Reineck, H.; Wunderlich, F. 1968. Classification and origin of flaser and lenticular bedding. Sedimentology 11: 99-104.

Retallack, G.J. 2001. Soils of the Past. An introduction to paleopedology. Blackwell Science: 404 p.

Riggi, J.C. 1957. Resumen geológico de la zona de los Lagos Pueyrredón y Posadas, Provincia de Santa Cruz. Revista de la Asociación Geológica Argentina 12 (2): 65-96.

Rusconi, C. 1965. Carlos Ameghino. Rasgos de su vida y su obra. Revista del Museo de Historia Natural de Mendoza 17: 1-162.

Russo, A.; Flores, M. A. 1972. Patagonia austral extraandina. In Geología Regional Argentina (Leanza, A.F.; editors). Academia Nacional de Ciencias de Córdoba: 809 p.

Shanley, K.W.; McCabe, P.J. 1994. Perspectives on the Sequence Stratigraphy of Continental Strata. American Association of Petroleum Geologists, Bulletin 78: 544-568.

Simpson, G.G. 1940. Review of the mammal-bearing Tertiary of South America. Proceedings of the American Philosophical Society 83: 649-709.

Tauber, A. 1994. Estratigrafía y vertebrados fósiles de la Formación Santa Cruz (Mioceno Inferior) en la costa Atlántica de Santa Cruz, República Argentina. Ph.D. Thesis (Unpublished), Universidad Nacional de Córdoba: 422 p.

Tauber, A.A. 1997a. Bioestratigrafía de la Formación Santa Cruz (Mioceno inferior) en el extremo sudeste de la Patagonia. Ameghiniana 34: 413-426.

Tauber, A.A. 1997b. Paleoecología de la Formación Santa Cruz (Mioceno inferior) en el extremo sudeste de la Patagonia. Ameghiniana 34: 517-529.

Tauber, A.A. 1999. Los vertebrados de la Formación Santa Cruz (Mioceno Inferior-Medio) en el extremo sureste de la Patagonia y su significado paleoecológico. Revista Española de Paleontología 14: 173-182.
Thomson, S.N. 2002. Late Cenozoic geomorphic and tectonic evolution of the Patagonian Andes between latitudes 428S and 468S: An appraisal based on fission-track results from the transpressional intraarc Liquiñe-Ofqui fault zone. Geological Society of America Bulletin 114: 1159-1173.

Thomson, S.T.; Brandon, M.T.; Tomkin, J.H.; Reiners, P.W.; Vásquez, C.; Wilson, N.J. 2010. Glaciation as a destructive and constructive control on mountain building. Nature 467: 313-317. doi:10.1038/nature09365.

Toledo, N. 2016. Paleobiological integration of Santacrucian sloths (early Miocene of Patagonia). Ameghiniana 53: 100-141.

Toledo, N.; Cassini, G.H.; Vizcaíno, S.F.; Bargo, M.S. 2014. Mass estimation in Santacrucian sloths from the Early Miocene Santa Cruz Formation of Patagonia, Argentina. Acta Paleontologica Polonica 59: 267-280.

Ugalde, R.; Bostelmann, E.; Buldrini, E.K.; Oyarzún, J.L. 2015. Lithofacies, architecture, and depositional environments of the Santa Cruz Formation in Chilean Patagonia. In Congreso Geológico Chileno, No. 14, Actas 1: 816-820. La Serena.

Ugarte, F.R.E. 1956. El grupo Río Zeballos en el flanco occidental de la Meseta Buenos Aires (Provincia de Santa Cruz). Revista de la Asociación Geológica Argentina 11 (3): 202-216.

Vizcaíno, S.F. 2011. Cartas para Florentino desde la Patagonia. Crónica de la correspondencia édita entre los hermanos Ameghino (1887-1902). Publicación Especial de la Asociación Paleontológica Argentina 12: 51-67.

Vizcaíno, S.F.; Bargo, M.S. 2013. Patagonia a Budapest: caminos europeos de fósiles santacrucenses (1845-1956). Revista de la Fundación Museo de La Plata 26: 36-42.

Vizcaíno, S.F.; Kay, R.F.; Bargo, M.S. 2012a. Early Miocene Paleobiology in Patagonia: high-latitude paleocommunities of the Santa Cruz Formation. Cambridge University Press: 392 p. Cambridge.

Vizcaíno, S.F.; Kay, R.F.; Bargo, M.S. 2012b. Background for a paleoecological study of the Santa Cruz Formation (late Early Miocene) on the Atlantic Coast of Patagonia. In Early Miocene Paleobiology in Patagonia: highlatitude paleocommunities of the Santa Cruz Formation (Vizcaíno, S.F.; Kay, R.F.; Bargo, M.S.; editors). Cambridge University Press: 1-22. Cambridge.

Vizcaíno, S.F.; Fernicola, J.C.; Bargo, M.S. 2012c. Paleobiology of Santacrucian glyptodonts and armadillos (Xenarthra, Cingulata). In Early Miocene Paleobiology in Patagonia: high-latitude paleocommunities of the Santa Cruz Formation (Vizcaíno, S.F.; Kay, R.F.; 
Bargo, M.S.; editors). Cambridge University Press: 194-215. Cambridge.

Vizcaíno, S.F.; Bargo, M.S.; Fernicola, J.C. 2013. Expediciones paleontológicas durante los siglos XIX y XX a la Formación Santa Cruz (Mioceno Inferior, Patagonia) y destino de los fósiles. In Congreso Argentino de Historia de la Geología, No. 3, Actas: 231-246. Salta.

Vizcaíno, S.F.; Fernicola, J.C.; Bargo, M.S.; Cuitiño J.I.; Kay, R.F.; Toledo, N.; Muñoz, N.A.; Hernández del Pino, S.; Spradley, J. 2015. Afloramientos fosilíferos de Cañadón de las Vacas (Formación Santa Cruz; Mioceno Temprano). Importancia bioestratigráfica y paleoecológica. In Jornadas Argentinas de Paleontología de Vertebrados, No. 29. Diamante.

Vizcaíno, S.F.; Brinkman, P.D.; Kay, R.F. 2016a. On the objectives and results of the Handel T. Martin paleontological expedition (1903-04) to the Santa Cruz Formation in southern Patagonia. Revista del Museo de La Plata, Special Number 1: 316-333.

Vizcaíno, S.F.; Bargo, M.S.; Cassini, G.H.; Toledo, N. 2016b. Forma y función en paleobiología de vertebrados.
Editorial de la Universidad Nacional de la Plata (Edulp): 268 p. http://sedici.unlp.edu.ar/handle/10915/55101.

Vizcaíno, S.F.; Bargo, M.S.; Fernicola, J.C.; Cuitiño, I.; Trayler, R.; Kohn, M.J.; Kay, R.F.; Toledo, N.; Muñoz, N.A. 2016c. The Cañadon de las Vacas-Rincón del Buque area: preliminary correlations with other Santacrucian (EarlyMiocene, Patagonia) localities. In Congreso de la Asociación Paleontológica Argentina, No. 11, Resúmenes: 102-103. Río Negro. Argentina.

Vucetich, M.G. 1994. La fauna de roedores de la Formación Cerro Boleadoras (Mioceno inferior?) en la provincia de Santa Cruz (Argentina). Acta Geologica Leopoldensia 39 (1): 365-374.

Windhausen, A. 1924. Líneas generales de la constitución geológica de la región situada al oeste del Golfo San Jorge. Boletín de la Academia Nacional de Ciencias 27: 167-320.

Zambrano, J.J.; Urien, C.M. 1970. Geological Outline of the Basins in Southern Argentina and Their Continuation off the Atlantic Shore. Journal of Geophysical Research 75: 1363-1396.

Manuscript received: December 4, 2017; revised/accepted: August 1, 2018; available online: February 4, 2019. 


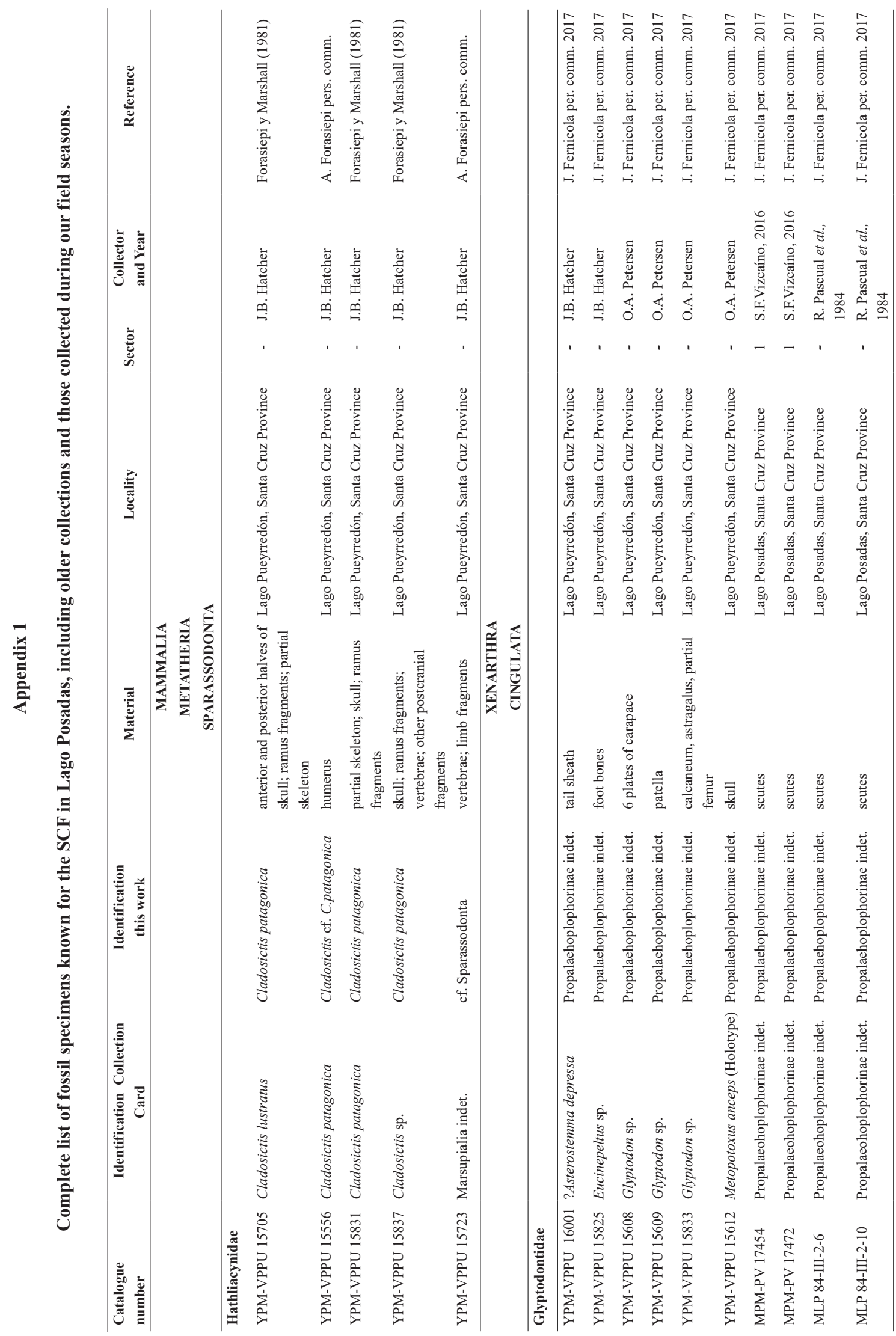




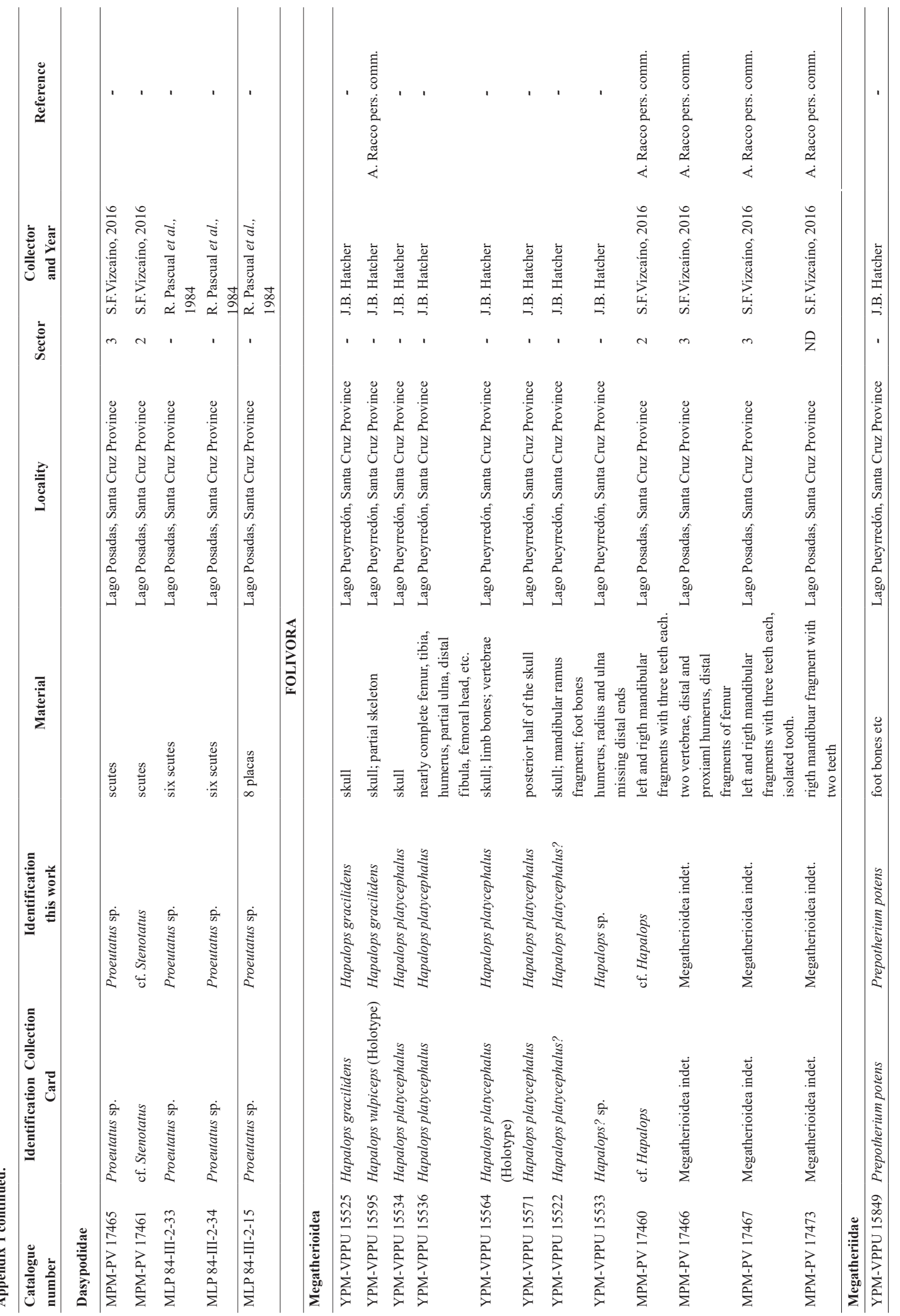




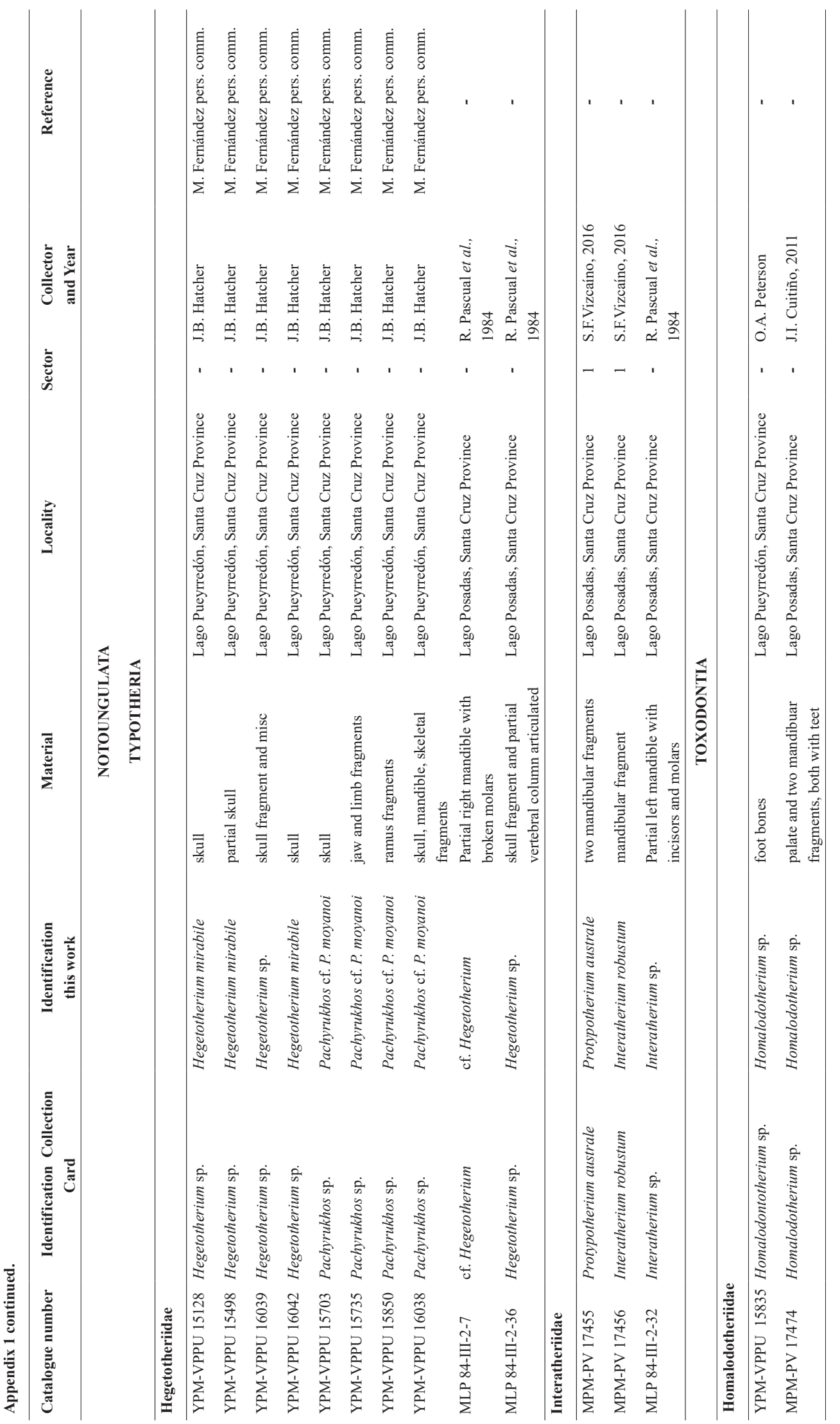




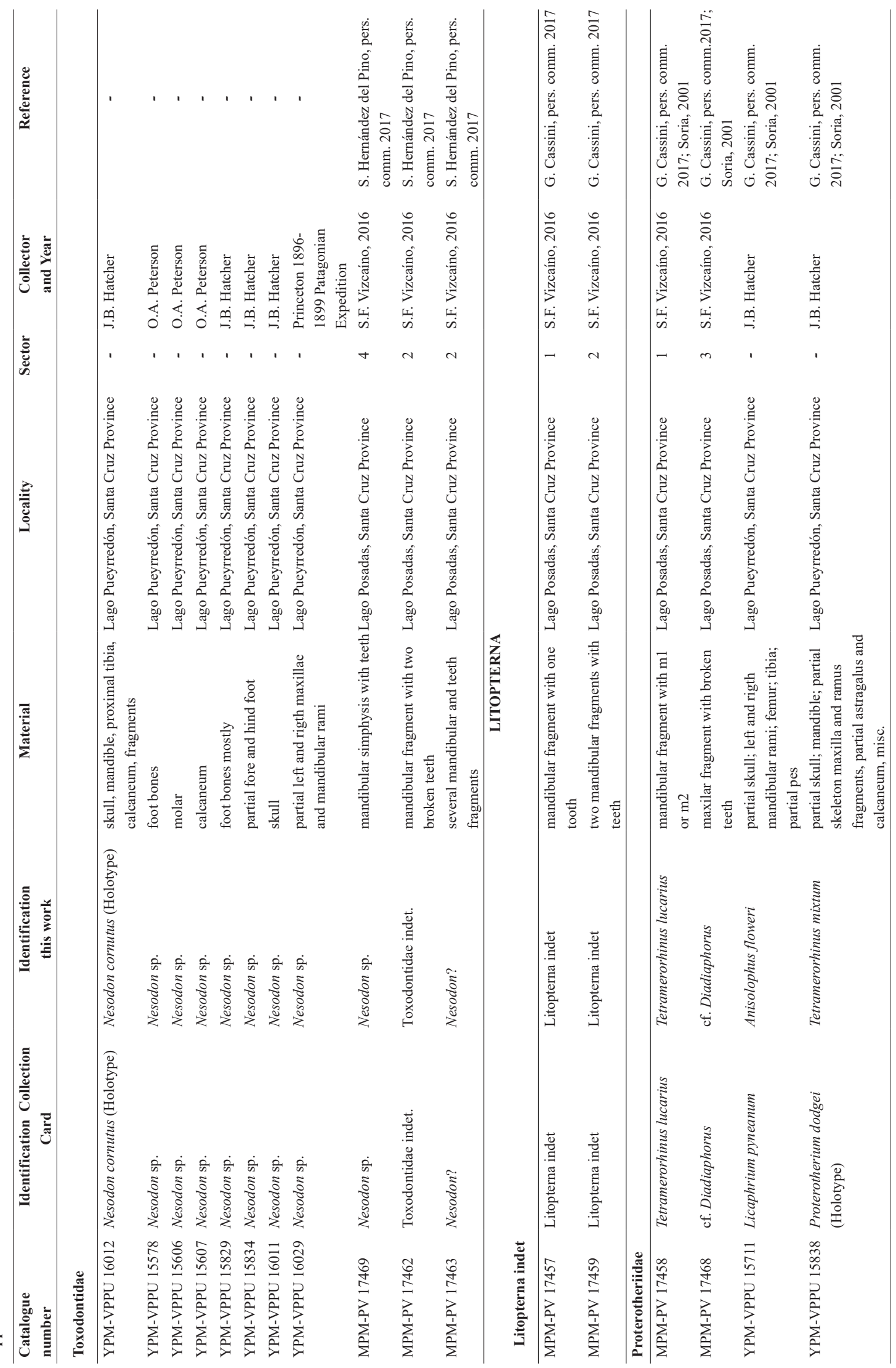




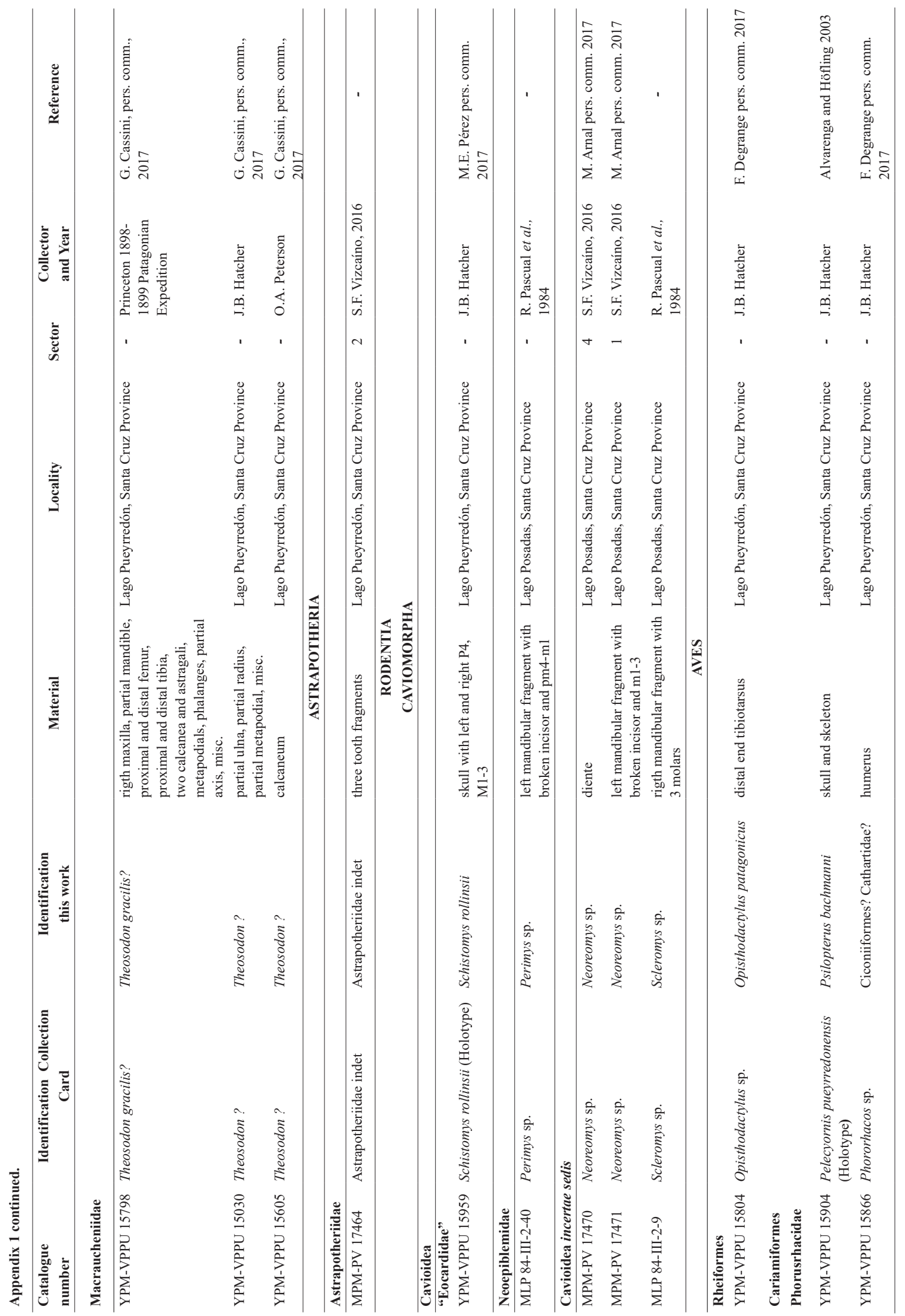

